Research article

urn:1sid:zoobank.org:pub:36FC5EA6-E82D-4E21-9060-030CF13ED1B7

\title{
Taxonomic revision of the Afrotropical genus Megatrigon Johnson, 1898 (Diptera: Syrphidae)
}

\author{
Dieter DOCZKAL ${ }^{1}$, Snežana RADENKOVIĆ ${ }^{2}$, Leif LYNEBORG ${ }^{3}$ \& Thomas PAPE ${ }^{4, *}$ \\ ${ }^{1}$ Bavarian State Collection of Zoology, Zoologische Staatssammlung, Munich, Germany. \\ ${ }^{2}$ University of Novi Sad, Department of Biology and Ecology, \\ Trg Dositeja Obradovica 2, 21000 Novi Sad, Serbia. \\ ${ }^{3}$ Deceased 10 September 2006, former address: Natural History Museum of Denmark, \\ Universitetsparken 15, 2100 Copenhagen, Denmark. \\ ${ }^{4}$ Natural History Museum of Denmark, Universitetsparken 15, 2100 Copenhagen, Denmark. \\ 1'Email: doczkal@zsm.mwn.de \\ ${ }^{2}$ Email: snezana.radenkovic@dbe.uns.ac.rs \\ ${ }^{4, *}$ Corresponding author: tpape@,snm.ku.dk \\ ${ }^{1}$ urn:Isid:zoobank.org:author:79800F7A-AA21-4948-AD64-619BD5FCBB98
${ }^{2}$ urn:1sid:zoobank.org:author:26DF35D9-55FA-4485-8E8C-C1F90EFE1036
${ }^{3}$ urn:Isid:zoobank.org:author:DAEF2A0D-7A43-4CF8-8E31-376C0B188EC6
${ }^{4} \underline{\text { urn:Isid:zoobank.org:author:1371BF99-D20A-47B9-BA9D-1F8D830A1B5A }}$
}

Abstract. The genus-group taxon Megatrigon Johnson, 1898, stat. nov., is revised and treated as a valid genus within the Merodontini (= Eumerini). Extensive diagnoses are given for the genus and for its three constituent species groups: argenteus group [11 spp.], nivalis group [monotypic], sexfasciatus group [3 spp.]. Five new generic combinations are proposed within Megatrigon: M. argenteus (Walker, 1852) comb. nov., M. flavimarginatus (Hull, 1964) comb. nov., M. jacobi (Hervé-Bazin, 1913) comb. nov., M. nivalis (Hull, 1964) comb. nov. and M. ochreatus (Hull, 1964) comb. nov. All species of the argenteus group are revised and nine new species are described: Megatrigon apiformis sp. nov., M. argentifrons sp. nov., M. argentimaculatus sp. nov., M. cooksoni sp. nov., M. immaculatus sp. nov., M. magnicornis sp. nov., M. natalensis sp. nov., M. sexmaculatus sp. nov., M. tabanoides sp. nov. Within the sexfasciatus group, M. jacobi (Hervé-Bazin, 1913) comb. nov. is treated as a senior synonym of Eumerus connexus Hull, 1964 syn. nov., but no further work is done at the species level due to insufficient material.

Keywords. Afrotropical, Megatrigon, Merodontini, Syrphidae, taxonomy.

Doczkal D., Radenković S., Lyneborg L. \& Pape T. 2016. Taxonomic revision of the Afrotropical genus Megatrigon Johnson, 1898 (Diptera: Syrphidae). European Journal of Taxonomy 238: 1-36. http://dx.doi.org/10.5852/ ejt.2016.238 


\section{Introduction}

The hover fly genus Eumerus Meigen, 1822 contains some 300 species (Pape \& Thompson 2010), that are generally medium-sized flies, with a distinctive habitus showing strong metalegs and a rounded or broadly oval abdomen. Larvae of all species, when known, are associated with various bulbs and tubers, although they may also develop in fruits and damaged or decaying parts of succulent plants (Ricarte et al. 2008) (the record of E. superbus Shannon, 1927 from a cycad cone ("reared from a Macrozamia cone, shipped from Australia"; Shannon 1927: 84) needs further study). Larvae are usually saprophagous although some appear to be at least partly phytophagous (Rotheray \& Gilbert 2011), and a few species are agricultural and horticultural pests (e.g., Ricarte et al. 2008). Adults are known as flower visitors and may be expected to be significant pollinators (Ssymank et al. 2008; Speight 2014). In a cladistic analysis of the tribe Merodontini Edwards, 1915 (= Eumerini Smirnov, 1924), Doczkal \& Pape (2009) provided strong evidence that Eumerus is paraphyletic with regard to a wellsupported 'Merodon clade' containing the genera Merodon Meigen, 1803, Platynochaetus Wiedemann, 1830, Lyneborgimyia Doczkal \& Pape, 2009 and Azpeytia Walker, 1865. Unexpectedly, two species, Eumerus argenteus Walker, 1852 and E. sexfasciatus (Johnson, 1898), emerged in their analysis as sister to the Merodon clade and this clade was given the informal name argenteus group. One of the included species, sexfasciatus, is the type species of the genus-group name Megatrigon Johnson, 1898, which has, however, not been recognized as valid by subsequent authors, and all species described from this group have been listed under Eumerus in recent catalogues and databases (Smith \& Vockeroth 1980; Pape \& Thompson 2010). At present, no fully resolved phylogenetic tree for the world fauna of Eumerus (s.l.) is available, but certain clades are already well supported, and we need names (formal or informal) for proper communication about them. The argenteus group sensu Doczkal \& Pape is very well characterised by several distinct autapomorphies (Doczkal \& Pape 2009), which makes this group one of the most strongly corroborated clades of the tribe Merodontini. We here initiate a splitting of Eumerus by re-instating and redefining the nominal genus Megatrigon Johnson, 1898. Diagnoses of the genus, of the three included species groups - argenteus group [11 spp.], nivalis group [monotypic], sexfasciatus group [3 spp.] - and of all species of the first two groups are given. The sexfasciatus group is left untreated at the species level due to insufficient material.

\section{Material and methods}

Only pinned, dry specimens were available, and when dissections were necessary the specimens were softened in a humidity chamber to allow for separation of the terminal segments with fine forceps and soaking the terminalia in $10 \% \mathrm{KOH}$ overnight at room temperature. After washing in water, acetic acid and again in water, male terminalia were transferred to glycerol for examination under a dissecting microscope at appropriate magnification. The terminalia were subsequently stored in a glass or plastic microvial pinned with the source specimen.

In order to facilitate the future recognition of undescribed species, all species treated are described employing the full set of taxonomically useful characters we have observed.

The specimens of Megatrigon available for the present study are deposited in the following collections:

AMGS = Albany Museum, Grahamstown, Eastern Cape, South Africa

BMNH $\quad=$ Natural History Museum, London, United Kingdom

CAS $\quad=$ California Academy of Sciences, California, San Francisco, USA

CSCA $=$ California State Collection of Arthropods, Sacramento, California, USA

MRAC $($ RMCA $)=$ Musée Royal de l'Afrique Centrale, Tervuren, Belgium

MZLU = Zoological Museum, Lund University, Lund, Sweden

NMSA $\quad=$ Natal Museum, Pietermaritzburg, KwaZulu-Natal, South Africa

RMNH = Naturalis Biodiversity Center [formerly Rijksmuseum van Natuurlijke Historie], Leiden, the Netherlands 


$$
\begin{array}{ll}
\text { SAMC } & \text { South African Museum (as part of the Iziko Museums), Cape Town, South Africa } \\
\text { UMO }(\text { OUMNH })= & \text { Oxford University Museum of Natural History, Oxford University, Oxford, United } \\
& \text { Kingdom } \\
= & \text { private collection of Werner Barkemeyer } \\
\text { coll. Bkm } & =\text { private collection of Martin Hauser (eventually to be deposited in CSCA) } \\
\text { coll. M. Hauser }
\end{array}
$$

A large part of the available specimens of Megatrigon is in more or less bad condition, i.e., damaged or dirty, and many have faded colours due to age and/or improper storage. Thus, the colours described here could be darker in fresh specimens. The often bad condition and the very low number of specimens (sometimes singletons only) of almost all species usually did not allow for cleaning or optimal preparation before taking photographs. For the preparation of the diagnoses of Megatrigon and the included species groups, all available specimens have been used (i.e., including the specimens of the sexfasciatus group, which are not treated at the species level in the present account). Identification of females is still unresolved, except for the distinct female of M. nivalis (Hull, 1964) comb. nov., but we have in a few cases listed females as paratypes or as additional material, although species descriptions are based on males only (with the noted exception of M. nivalis).

\title{
Terminology
}

Morphological terminology follows mainly McAlpine (1981) for the non-genitalic morphology, Stuckenberg (1999) for the antenna, and Sinclair (2000) for the structures of the male terminalia, with terms for characters not treated there adopted from Speight (1987), Hippa \& Ståhls (2005) and Doczkal \& Pape (2009).

\section{Results}

\author{
Animalia Linnaeus, 1758 \\ Arthropoda Latreille, 1829 \\ Insecta Linnaeus, 1758 \\ Diptera Linnaeus, 1758 \\ Syrphidae Latreille, 1802 \\ Eristalinae Newman, 1834 \\ Merodontini Edwards, 1915
}

Megatrigon Johnson, 1898: 159 stat. nov. (resurrected as a valid genus from the synonymy with Eumerus Meigen, 1822).

\section{Originally included species}

Megatrigon sexfasciatus Johnson, 1898.

\section{Type species}

Megatrigon sexfasciatus Johnson, 1898 (holotype, ㅇ (BMNH), examined), by original designation.

\section{Remarks}

The holotype is without the posteroventral patch of setae on katepisternum. This is quite unusual among Megatrigon and all other Merodontini (currently only known from Lyneborgimyia magnifica Doczkal \& Pape, 2009) and probably this is an individual aberration (the number of posteroventral katepisternal setae is very low - usually less than 10 - in most Megatrigon, lower than usually seen in the Merodontini). In all other characters this specimen fits the diagnosis of Megatrigon given below. The male of Megatrigon sexfasciatus is unknown (probably not present in the available material). 


\section{Diagnosis}

With all autapomorphies of the Merodontini (Doczkal \& Pape 2009; as Eumerini) except for the colour of the pterostigma, which is clear in most species. Unique characters (autapomorphies) within Merodontini are:

1) lower calypter setose dorsally,

2) metafemur posterodorsally on proximal half obliquely striate (Fig. 6A-B),

3) stem vein $R$ without setae (if exceptionally one or a few setae are present then they are no longer than $0.5 \times$ the width of the vein),

4) tergite 1 laterally (lateral to the apex of metepimeron) bare,

5) tergite 2 anterolaterally with a large triangular bare area (Fig. 9A),

6) hamus characteristically S-shaped (Fig. 11N:x),

7) subepandrial sclerite with long microtrichia (Figs 10B:w, 13C-D, G:z).

\section{Description}

HEAD. Lateral corners of mouth edge well developed, anterior edge of mouth slightly produced (except for Megatrigon jacobi (Hervé-Bazin, 1913) comb. nov.), dorsal part of face more or less distinctly convex below antenna, median part of lunula extended posteriorly (similar to Merodon), both dorsal and ventral part of post-ocular orbit wide, post-ocular ridge present, postcranial carina absent, dichoptic (Fig. 2), eye setose, without enlarged ommatidia in $\widehat{\partial}$. Fossette ill-defined, in a lateral position, postpedicel without longitudinal furrows, arista simple. Clypeus slender, postclypeus well sclerotized, labellum elongated (as in many Merodon).

Thorax. Notopleural sulcus absent, notal wing process of Eumerus-type, supra-alar bristles well developed, their alveoli enlarged, scutal alveoli with raised margins, post-alar callus nearly entirely setose, scutellum $>2 \times$ as wide as long, its marginal rim yellow, scutellum with concave ventral surface, without ventral fringe, probasisternum large, approaching proepisternum, proepimeron moderately extended ventrally [as in Eumerus tricolor (Fabricius, 1798)], katepimeron almost flat, katatergite with a weak carina, metepisternum bare.

WING (Fig. 5). Cross-vein sc-r well developed, $C$ ending far before apex of wing, $\mathrm{R}_{4+5}$ moderately sinuous (as in Eumerus tricolor), $\mathrm{M}_{1}$ without stump veins, $\mathrm{dm}$-cu almost perpendicular to $\mathrm{Cu} \mathrm{A}_{1}$, usually with stump vein, $\mathrm{CuA}_{1}$ slightly more than $2 \mathrm{x}$ as long as $\mathrm{dm}-\mathrm{cu}$, bm-cu about as long as basal part of $\mathrm{CuA}_{1}$ or slightly longer, $\mathrm{CuA}$ about $3 \mathrm{x}$ as long as $\mathrm{CuA}_{2}, \mathrm{~A}_{1}+\mathrm{CuA}_{2}$ smoothly curved, Cup short and ending at about half length of $\mathrm{CuA}$, wing broad, about $2.35 \times$ as long as wide, wing margin with undulated membrane, costagium with long setae at posterior margin (except in Megatrigon nivalis), marginal fringe of upper calypter 'glued' (cf. fig. 32I-K in Hippa \& Ståhls 2005).

Legs. Procoxa short and stout, mesocoxa posteriorly usually bare (except for M. jacobi comb. nov.); metafemur shiny, thickened and curved dorsally, about $2.5 \times$ as long as deep, light yellow setae on metafemur exceed relatively large apical flange, usually with shiny, bare, longitudinal area ventrally; ventral face of metafemur slightly convex or straight, with a low anteroventral preapical flange bearing weak bristles on strong finger-like outgrowths, and with a few weak bristles posteroventrally preapically (Fig. 6C); metatibia with a sharp bare (a few isolated setae may occur) anteroventral ridge in proximal half, protibia with irregularly spaced anterolateral apical setae; protarsus short and stout, tarsomeres 2-4 as wide as long; claws enlarged.

ABDOMEN. Tergites strongly curved ventrally at margin; anterior corners of tergite 2 inflated, border between tergites 1 and 2 not crenulated; lateral margins of tergites microtrichiose; $\hat{0}$ sternite 4 without projections, with incised posterior margin and a fine desclerotised median line, lateral margins simple, sternite 6 bare, sternite 7 with a basal bump. Anterior surstyle lobe absent, posterior surstyle lobe narrow 
(Fig. 13A, E:y), subepandrial sclerite microtrichiose (Fig. 13C-D, G:z). Setae on various part of the body serrated (Fig. 9B), except in M. nivalis comb. nov. The included species can be arranged into three well defined species groups, each defined by several autapomorphic character states.

\section{nivalis group}

\section{Diagnosis}

Katepisternum posteriorly setose on full width $(\widehat{)})$ or with a small gap above the ventral pile patch $(+)$ ). Anepisternal setae thick, glistening, without serration. Base of wing extensively bare of microtrichia, including parts of cells c, $\mathrm{r}_{1}, \mathrm{br}, \mathrm{bm}$, cup, and narrow stripes along the longitudinal veins. The bare flat posterior margin of tergite 1 extensively microtrichiose. 0 : Sternite 4 with flat caudal lobes, entirely microtrichiose. Genital pouch about half as wide as abdominal segment 4 at anterior margin. Male genitalia (Figs 10M, 11M-N, 12L): posterior surstyle lobe directed caudally, fused with median surstyle lobe for most of its length, with a sharp ridge at the border with median lobe, apex of posterior lobe with a small hook. Median surstyle lobe setose on about the posterior 0.67 of outer and ventral surface, on median surface covered by microtrichia on most part and with a sharp longitudinal ridge near dorsal border on about posterior half. Cerci with blunt apex, ventral surface membraneous and without setae. Subepandrial sclerite strongly curved (in lateral view), and its anterior end sclerotized at the sides only, sclerotized but translucent in the middle, the posterior part microtrichiose on nearly full length, without trichiose pillow-like structure. Hypandrium with a moderately wide base in ventral view and narrow in lateral view, with a transverse bulge immediately anterior to the attachment of the phallus, without 'shoulders' between wide base and narrower distal half, apex slightly produced beyond ctenidium and blunt. Ejaculatory apodeme small. + : tergite 5 (Fig. 8A, B:x) and sternite 5 with anteriorly directed setae, ovipositor with thick blunt setae and a dorsal subapical tooth (Fig. 8C:y).

The nivalis group contains a single species.

Megatrigon nivalis (Hull, 1964), comb. nov.

Figs $1 \mathrm{M}, 2 \mathrm{~N}, 3 \mathrm{M}, 4 \mathrm{D}, 8,10 \mathrm{M}, 11 \mathrm{M}-\mathrm{N}, 12 \mathrm{~L}, 16$

Eumerus nivalis Hull, 1964: 485. Type locality: South Africa, Northern Cape, Belmont.

\section{Diagnosis}

See diagnosis of nivalis group.

\section{Type material}

SOUTH AFRICA: $\hat{\jmath}$, holotype, Northern Cape, Belmont, 23 Feb. 1934, J. Ogilvie (BMNH). [Examined.] The holotype is in bad condition, with both metalegs and right mesoleg missing (all from femur on), head glued to the thorax, left mesoleg soaked in an unknown substance.

\section{Additional material}

NAMIBIA: 1 đૈ, Rundu, 31 Jan. 1993, leg. M. Schwarz (coll. M. Hauser); 1 , same locality, 22 Jan. 1993, leg. J. Gusenleitner (coll. M. Hauser).

\section{Description}

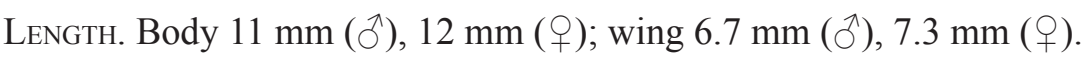

HEAD (Figs 2N, 3M). Face completely densely microtrichiose, only the slightly produced anterior mouth edge and a small area posterior to lateral mouth corner bare of microtrichia. Frons with a dense silver pilosity. Distance between eyes small $(0.11 \times$ width of head). Vertical triangle microtrichiose except 


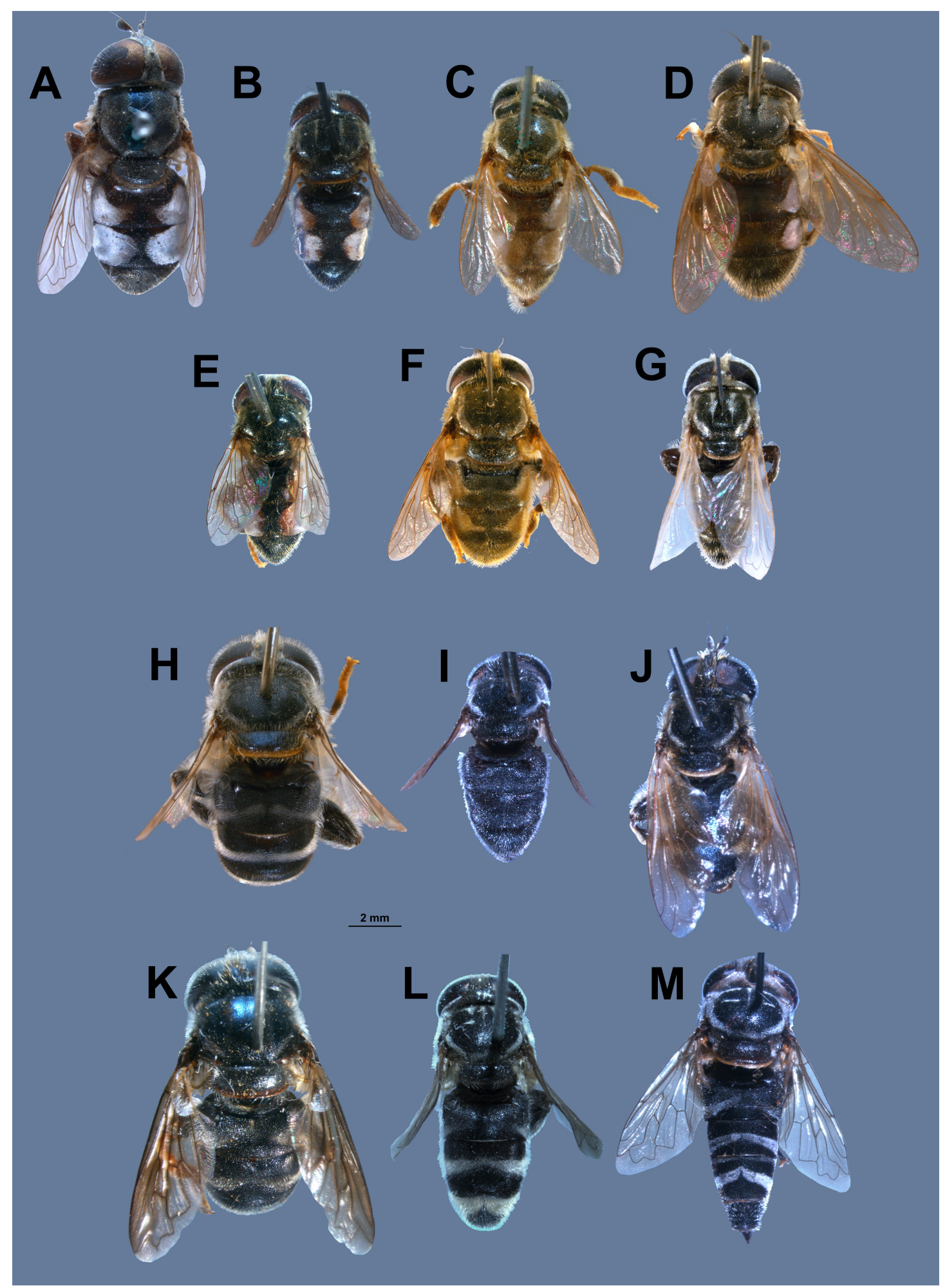

Fig. 1. Megatrigon spp., habitus, dorsal view. A. Megatrigon argenteus (Walker, 1852) comb. nov. (đ). B. $M$. argentifrons sp. nov. (§). C. M. argentimaculatus sp. nov. (§). D. M. magnicornis sp. nov. (§). E. M. natalensis sp. nov. (§). F. M. sexmaculatus sp. nov. (ठ). G. M. apiformis sp. nov. (ठ). H. M. cooksoni sp. nov. (ð). I. M. immaculatus sp. nov. (ð). J. M. ochreatus (Hull, 1964) comb. nov. (ð). K. M. tabanoides sp. nov. (ð). L. M. jacobi (Hervé-Bazin, 1913) comb. nov. (ठ)). M. M. nivalis (Hull, 1964) comb. nov. (+). 
for between and posterior to the posterior ocelli, postocellar spot small, microtrichiose very narrowly continuing along parasagittal sulci, postocular orbit behind postocular ridge with sparse microtrichia. Postocular area wide, about $1.5 \times$ as wide behind dorsal eye corner than at the narrowest point on ventral half. Posterior eye margin slightly bent anteriorly dorsal to vortex. An ill-defined median furrow on vertex from posterior ocelli to posterior border. Ocellar triangle isosceles. Antenna black, base of

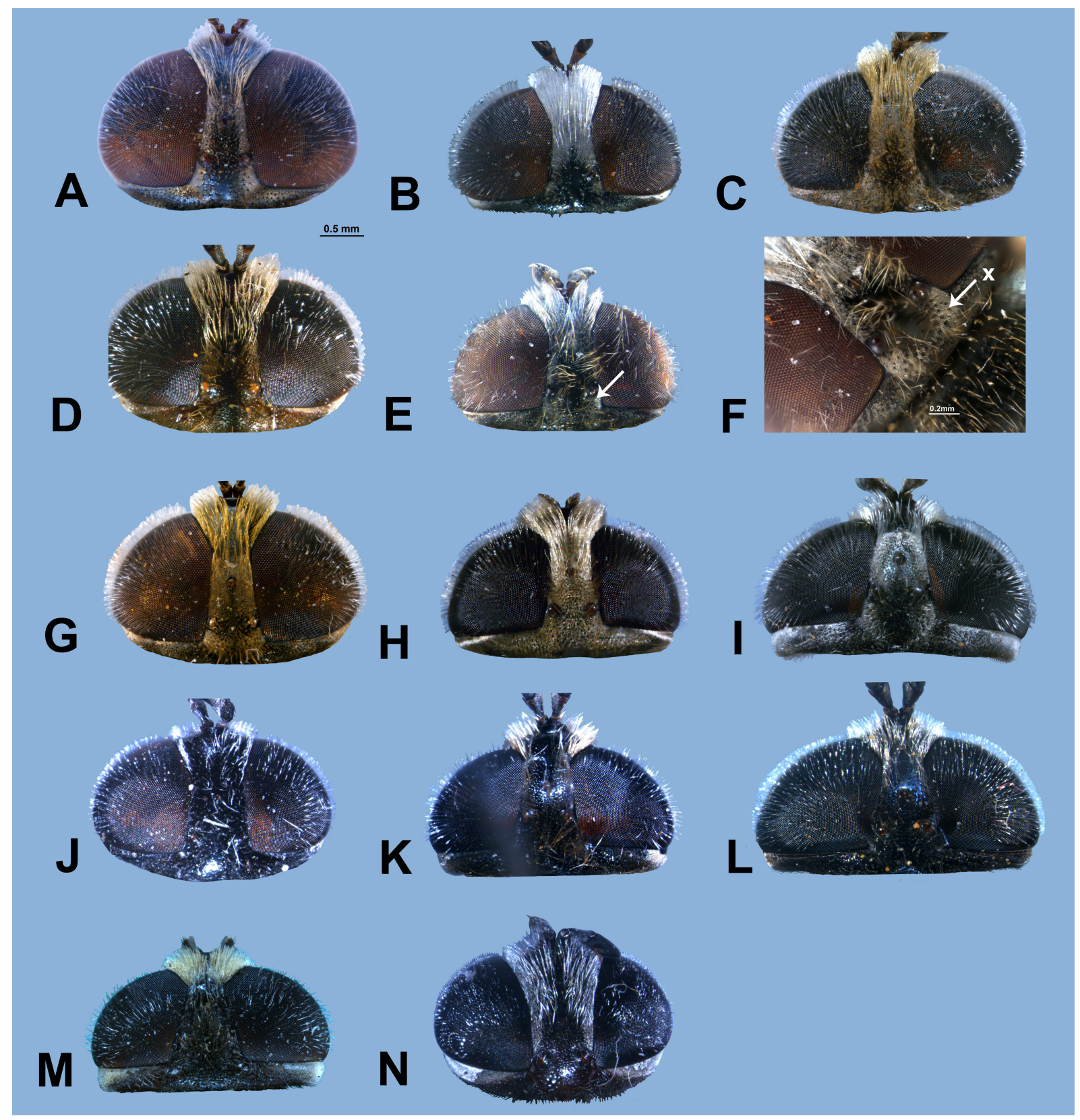

Fig. 2. Megatrigon spp., head, dorsal view. A. Megatrigon argenteus (Walker, 1852) comb. nov. (ठ).

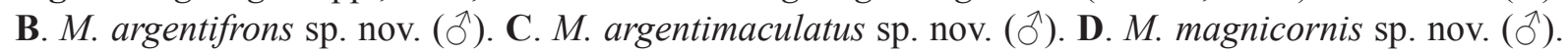
E-F.M. natalensis sp. nov. (arrow = postocellar spot) $($ (). G. M. sexmaculatus sp. nov. (ð). H. M. apiformis sp. nov. (ठ). I. M. cooksoni sp. nov. (ð). J. M. immaculatus sp. nov. (ð). K. M. ochreatus (Hull, 1964) comb. nov. $\left({ }^{\Uparrow}\right)$. L. M. tabanoides sp. nov. (đ). M. M. jacobi (Hervé-Bazin, 1913) comb. nov. (ठ). N. M. nivalis (Hull, 1964) comb. nov. (+). Symbol: $\mathrm{x}=$ postocellar spot. 


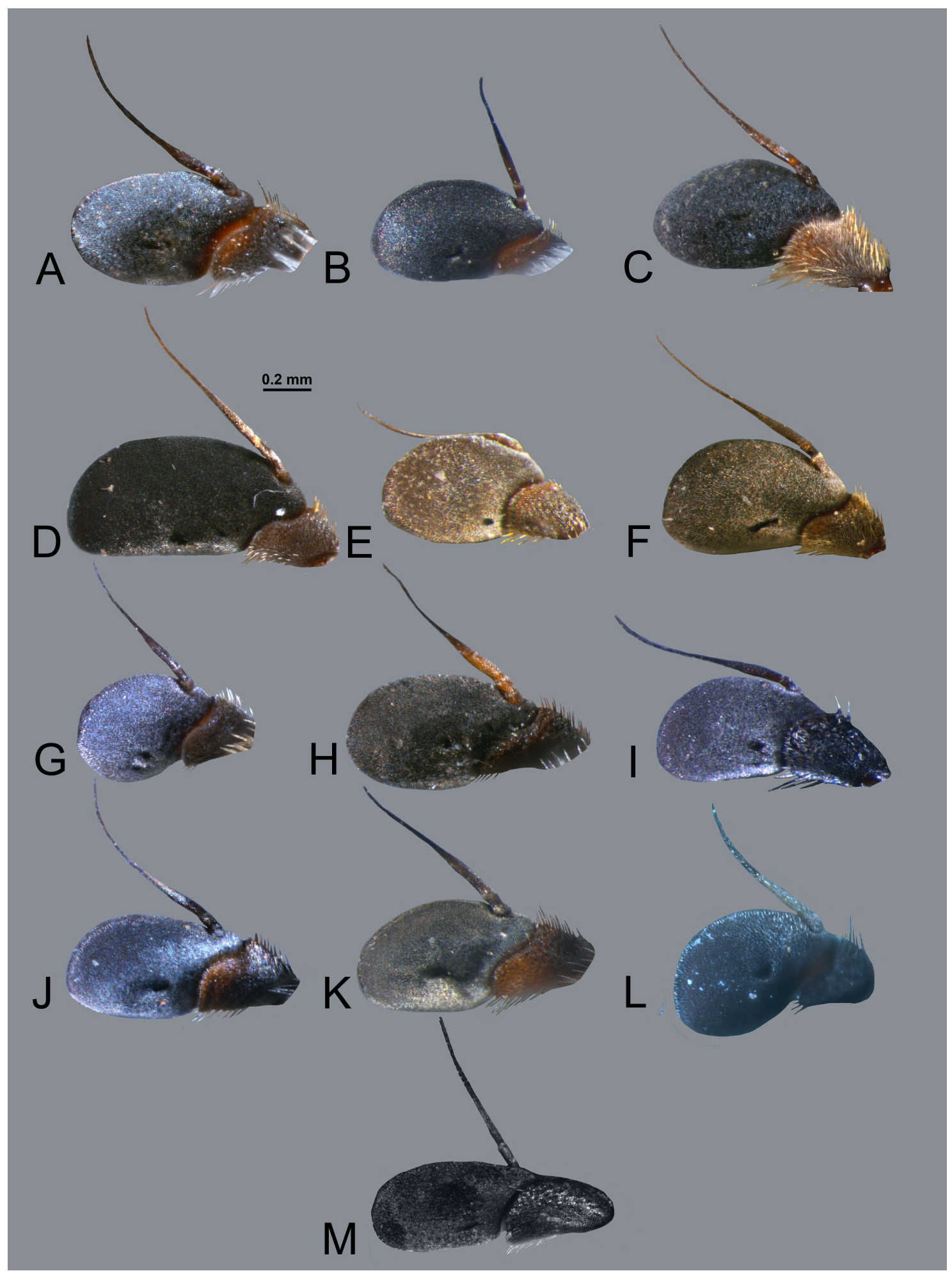

Fig. 3. Megatrigon spp., left antenna, lateral view. A. Megatrigon argenteus (Walker, 1852) comb. nov. (ठ). B. M. argentifrons sp. nov. (§). C. M. argentimaculatus sp. nov. (ð). D. M. magnicornis sp. nov. (ð). E. M. natalensis sp. nov. (ठ). F. M. sexmaculatus sp. nov. (ð). G. M. apiformis sp. nov. (ठ). H. M. cooksoni sp. nov. (ठ). I. M. immaculatus sp. nov. (ð). J. M. ochreatus (Hull, 1964) comb. nov. (ð)). K. M. tabanoides sp. nov. (ठ)). L. M. jacobi (Hervé-Bazin, 1913) comb. nov. (đ)). M. M. nivalis (Hull, 1964) comb. nov. (+). 
arista bright orange. Pedicel slightly elongate, postpedicel small, oval, sensory pit elongated, forming an oblique slit.

Thorax (Fig. 4D). Mesoscutum extensively and densely microtrichiose: median and submedian stripes extending to the level of wing base (the submedian stripes missing in female, Fig. 4D), notopleuron, supraalar area, prescutellar area, transverse suture (the latter incomplete in female, Fig. 4D). Scutal pilosity short, semi-decumbent, light (whitish), supraalar setae uniserial (with few extraserial setae), yellow. Notal wing process microtrichiose. Capitulum blackish. Setae on anterior part of anepisternum restricted to posterodorsal half. Proepimeron with long setae. Thoracic pleura bare of microtrichia on posterior part of anepisternum, on katepisternum anterior to the setose parts, and all of meron (lower part dulled by a fine surface sculpture). Protarsus shorter than protibia, stout; tarsomere 1 about as long as wide. Profemur and protibia reddish brown will ill-defined blackened parts, densely microtrichiose posteriorly and dorsally (obscuring surface), thinly microtrichiose anteriorly and ventrally, pilosity white. Tarsomeres $2-5$ darkened dorsally.

WING. Costagium with yellow setae, posterior setae short (about as long as diameter of costa distal to costagium). Cells c, $r_{1}$, bm, cup and anal lobe with large areas bare of microtrichia, as well as narrow bare stripes along parts of the veins and at the posterior margin of the wing including alula, veins yellowish brown at base, darker brown towards apex.

Abdomen (Fig. 8). Conical [similar to Merodon avidus (Rossi, 1790)], lateral margins of tergite 2 convergent posteriorly, tergite 3 is $2 \times$ as wide as long, tergite 2 with a median fascia, tergites $3+4$ each microtrichiose anteriorly and with a median fascia, tergite 4 with microtrichiose posterior margin. Tergite

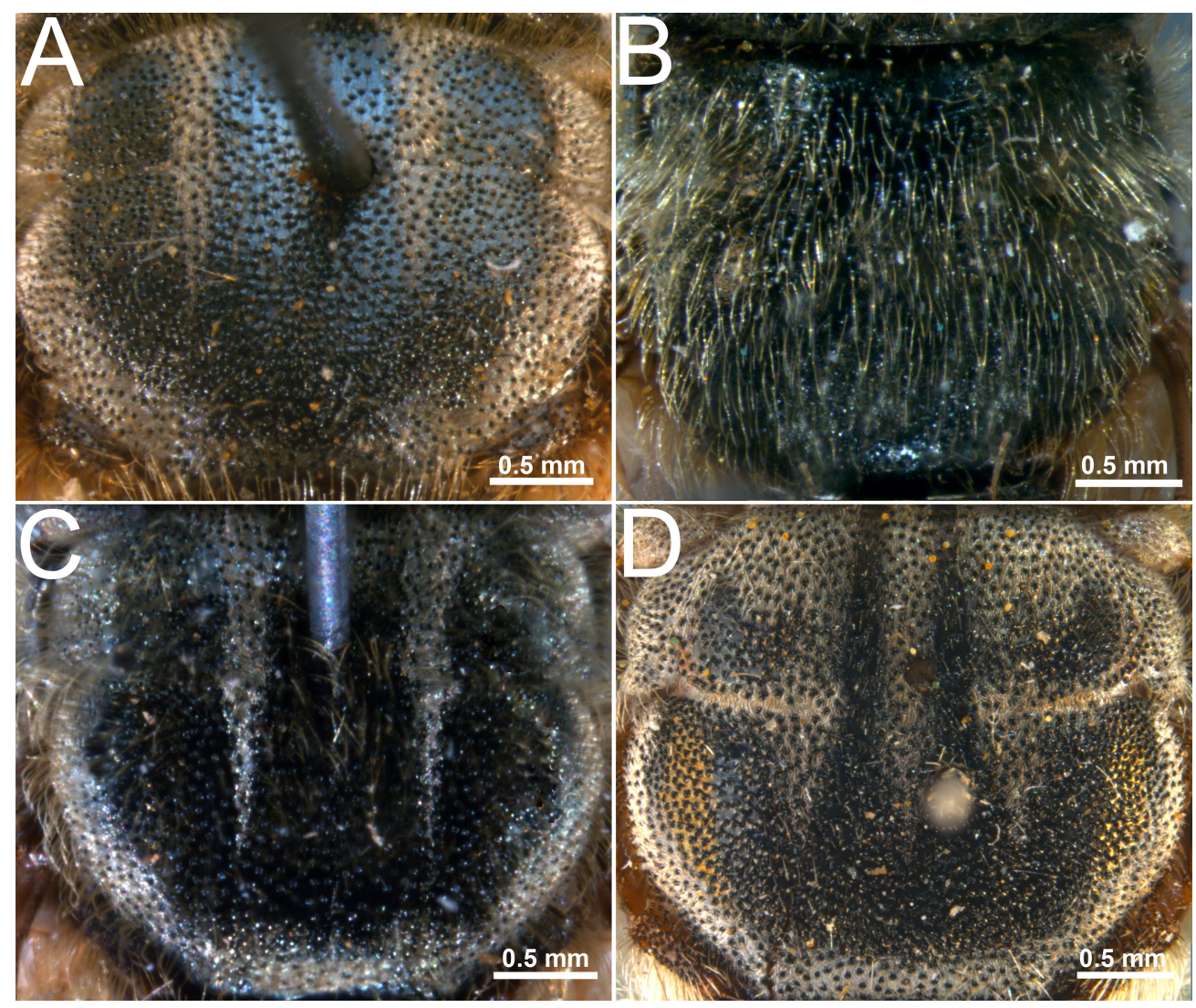

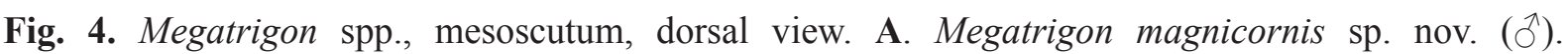
B. M. natalensis sp. nov. (§). C. M. apiformis sp. nov. (ð). D. M. nivalis (Hull, 1964) comb. nov. (ठ)). 
2 posteromedially (posterior to fascia) with a large triangular black setose area, most part of tergite 3 (except for fascia and lateral margins) black setose, tergite 4 with small black setose area between anterior and median fascia, otherwise tergites with whitish pilosity. Except for the lateral margin setae are very short, those on posterior margin of tergite 2 not distinctly exceeding margin of tergite, tergites pitted (alveoli). Genital pouch wider than half width of tergite 4 anteriorly. Sternite 1 large. Sternites 2-4 with semi-decumbent, comparatively short, white setae.

\section{Distribution}

Afrotropical - Namibia, South Africa (Fig. 16).

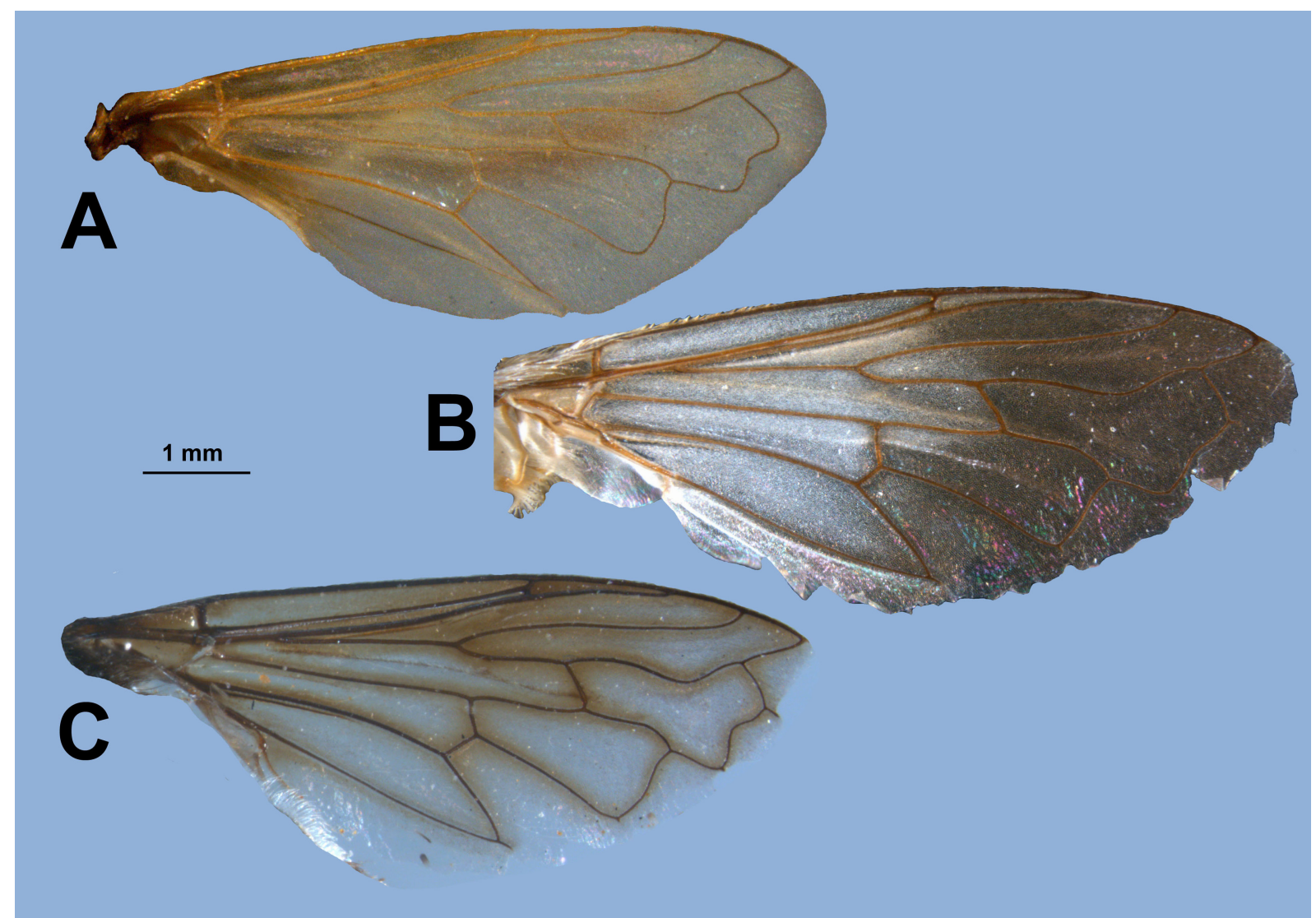

Fig. 5. Megatrigon spp., right wing, $\widehat{~}$. A. Megatrigon apiformis sp. nov. B. M. cooksoni sp. nov. C. M. tabanoides sp. nov.

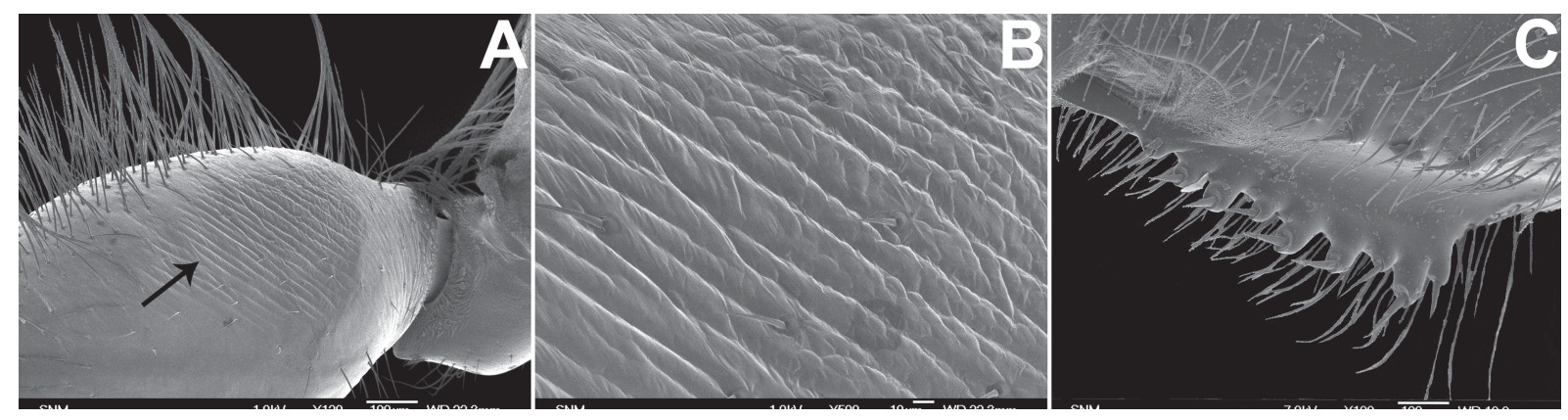

Fig. 6. Megatrigon spp., metafemur, $\widehat{\jmath}$ (SEM). A. Megatrigon argentifrons sp. nov., proximal half posterodorsally with striae (arrow). B. M. argentifrons sp. nov., enlarged striae. C. M. magnicornis sp. nov., anteroventral preapical flange. 


\section{argenteus group}

\section{Diagnosis}

Katepisternum with a posterodorsal and a weak (composed of a few setae only) posteroventral pile patch, without setae between them. The bare flat posterior margin of tergite 1 (almost) entirely without microtrichia. Base of wing entirely microtrichiose or at most with small bare areas in cells br, bm, or cup. Anepisternal setae saw-like. Protarsomere 1 anterodorsally with a line of minute black spinules (yellow in M. argentimaculatus sp. nov. and M. tabanoides sp. nov.) between the yellow trichia.

ô: sternite 4 with flat caudal lobes, entirely microtrichiose. Genital pouch less than half as wide as abdominal segment 4 at anterior margin. Posterior surstyle lobe directed medially, its apex forming a strong twisted hook (Fig. 13A:y). Median surstyle lobe setose along ventral margin on full length, on median surface extensively covered by microtrichia and posteriorly with a small inner accessory lobe pointing medially (Fig. 13D:x). Cerci (Fig. 10:z) with blunt apex, ventral surface membraneous and without setae. Subepandrial sclerite strongly curved (in lateral view, Fig. 10:w), and its anterior end sclerotized at the sides only, sclerotized but translucent in the middle, posterior part with a strongly trichiose pillow-like structure, which is densely furnished by unusually long and thick microtrichia (Fig. 13C, D:Z), otherwise bare. Hypandrium (Fig. 12:A-J) with a moderately wide base (in ventral view), without 'shoulders' between wide base and narrower distal half, apex distinctly produced beyond ctenidium and pointed. Ejaculatory apodeme small. The male terminalia of all included species are very similar (Figs 10-12), the significance of the observed small differences between species needs to be proved by more material.

Q⿱ : tergite 5 and sternite 5 with posteriorly directed setae, ovipositor with moderately thick setae, without tooth.

The argenteus group can be subdivided into two subgroups, at least the first being monophyletic. A full description is given for M. argenteus comb. nov., which is the only fairly common species of this group (all others being rare or known from singletons only). The descriptions of the remaining species focus on the differences to $M$. argenteus.

\section{Subgroup 1}

Male tergites $2+3$ flattened and with 'silver spots' (= patches of very dense silvery reflecting microtrichia) (not present in ${ }_{+}$).

Megatrigon argenteus (Walker, 1852) comb. nov.

Figs 1A, 2A, 3A, 7A, 9, 10A, 11A, 12A, 13A-C, 14, 15

Eumerus argenteus Walker, 1852: 224. Type locality: South Africa, Western Cape, Cape of Good Hope. Eumerus quadrimaculatus Macquart, 1855: 111. Type locality: South Africa, Western Cape, Cape of Good Hope.

\section{Diagnosis}

Costagial setae black. Ocellar triangle with a shallow longitudinal groove. Mesofemur anteriorly black setose. Metatibia in proximal half dorsally with reduced microtrichia, not reaching scar. Silver spots on tergite 3 are $1.4 \times$ as wide as long; tergite 4 with a pair of isolated submedian microtrichiose spots (Figs 1A, 7A). 


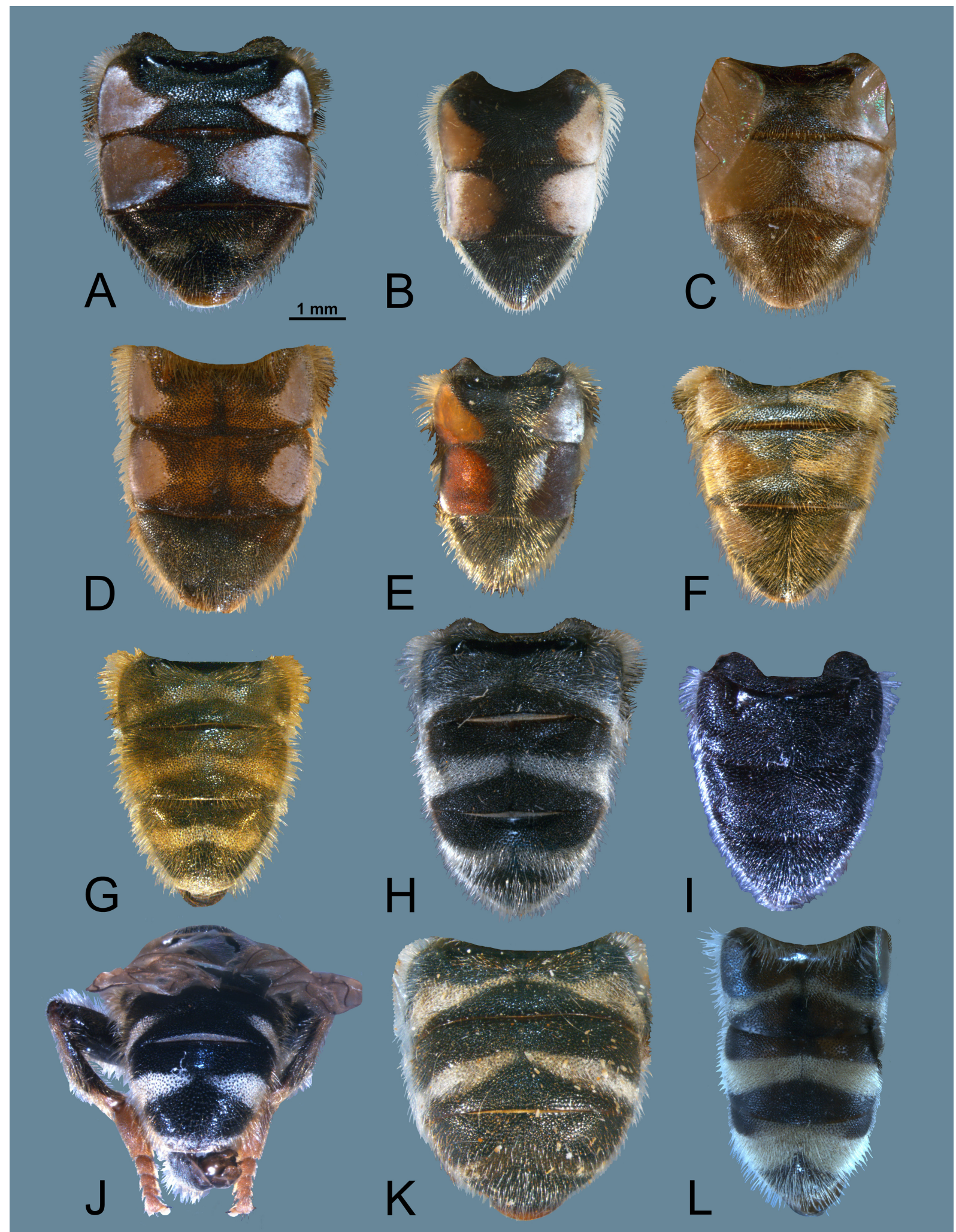

Fig. 7. Megatrigon spp., abdomen, dorsal view, ô. A. Megatrigon argenteus (Walker, 1852) comb. nov. B. M. argentifrons sp. nov. C. M. argentimaculatus sp. nov. D. M. magnicornis sp. nov. E. M. natalensis sp. nov. F. M. sexmaculatus sp. nov. G. M. apiformis sp. nov. H. M. cooksoni sp. nov. I. M. immaculatus sp. nov. J. M. ochreatus (Hull, 1964) comb. nov. K. M. tabanoides sp. nov. L. M. jacobi (Hervé-Bazin, 1913) comb. nov. 


\section{Type material}

SOUTH AFRICA: ${ }^{\lambda}$, holotype of argenteus [not $q$ as given by Walker]: "Cape" (BMNH). [Examined by Nigel Wyatt.]

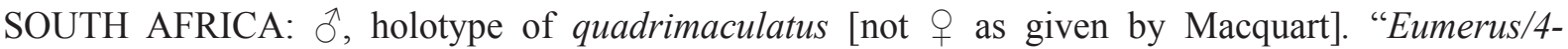
maculatus/o. Macq." (original Macquart label), "E. quadrimaculatus/ex. Coll. Bigot" (non-original label) (UMO). Macquart (1855: 111) states "Cap de Bonne Espérance" as the type locality. [Examined.]

\section{Additional material}

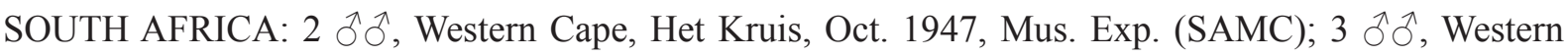

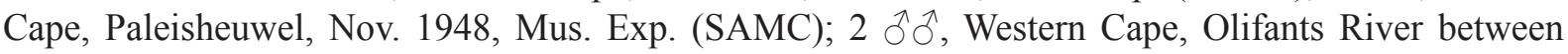
Citrusdal and Clanwilliam, Oct.-Nov. 1931, Museum staff leg. (SAMC); 1 O, Western Cape, Citrusdal,

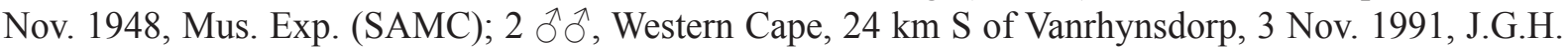
Londt leg. (NMSA); 1 गे, Western Cape, 2 km NW of Darling, 4 Oct. 1994, R. Danielsson leg. (MZLU); 1 ô, Western Cape, Cederberg, 21 km S of Clanwilliam, 22 Nov. 2002, W. Barkemeyer leg. (coll. Bkm);

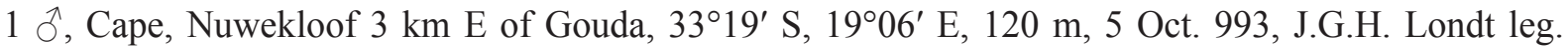

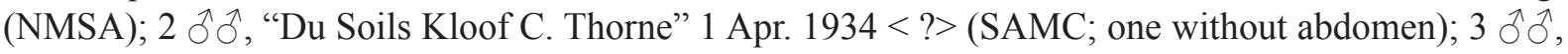
1 , 6 exuviae (SAMC; no data).

MALAWI: 1 ð, Kasungu Nat. Park, Lifupa Camp, 1333Aa, 1000 m, 9-10 Dec. 1980, Stuckenberg \& Londt leg., Brachystegia (NMSA).

\section{Description}

LENGTH. Body 7.0-11.0 mm, wing 5.0-6.5 mm.

HeAd (Figs 2A, 3A). Ellipsoidal in frontal view (about $1.3 \times$ as wide as deep); in lateral view about $1.5 \times$ as deep as long; dichoptic eyes, distance between eyes relatively small, $0.13-0.14 \times$ width of head; cuticle of head capsule brown-metallic bronze, shiny; face covered with long white setae; shiny,

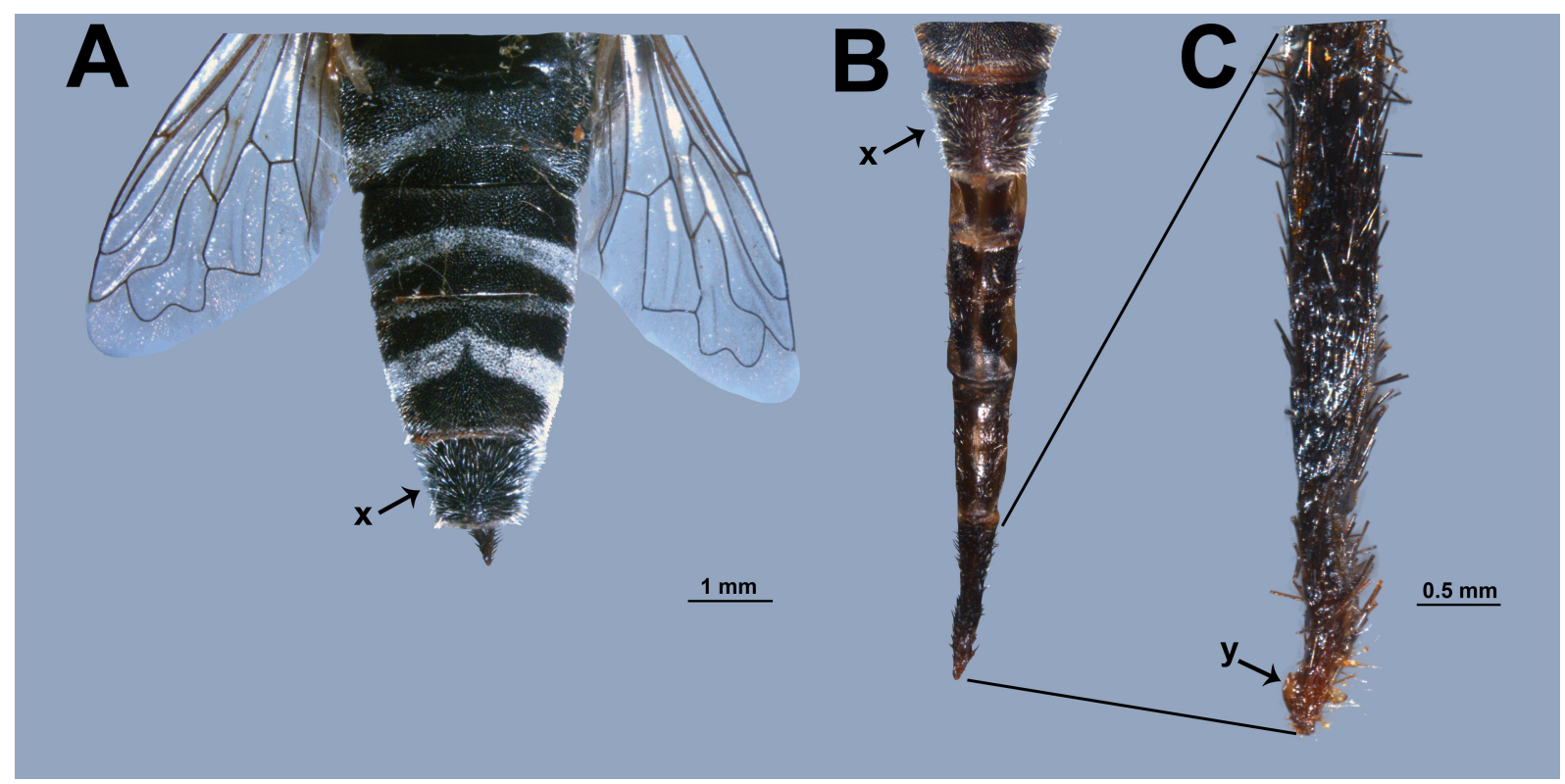

Fig. 8. Megatrigon nivalis (Hull, 1964) comb. nov., abdomen, dorsal view, ․ . A. Habitus, Terminalia withdrawn. B. Terminalia extended. C. Ovipositor. Symbols: $\mathrm{x}=$ tergite $5 ; \mathrm{y}=$ subapical tooth. 
except narrow, short microtrichiose stripes along eye margins (missing in lower part), and median facial stripe wide below antennae (in some specimens connected with microtrichia along eye margin) and then tapering towards mouth edge; the width of face $0.37-0.38 \times$ width of head; frons with semi-erect yellow setae, cuticle well visible, shiny; sometimes with reduced stripes of microtrichia near the eye margins; vertex covered with long, dark yellow setae (sometimes dark brown); shiny in the central part, but microtrichiose anteriorly (around front ocellus), laterally, along the eye margin, postocellar microtrichiose spots relatively small, separated by the distance between posterior ocelli; the width of vertical triangle $0.22-0.25 \times$ width of head; microtrichia on post-ocular orbit dense, dorsally narrowly exceed postocular ridge and connected with postocellar microtrichiose spots, postocular orbit dorsally only little wider than at its narrowest part, $0.08 \times$ width of head; ocellar triangle almost isosceles; with median longitudinal groove; antenna (Fig. 3A) brown, sometimes pedicel paler (orange brown) than postpedicel or end of pedicel and beginning of pospedicel paler (orange brown); setae on scape and pedicel predominantly white, except brown setae on dorsal part; postpedicel ellipsoidal, about $1.5 \times$ as long as deep; $1.7-1.8 \times$ as long as pedicel.

THORAX. Scutum black, laterally with golden lustre, anteriorly on median part dark blue, covered with moderately long, mostly relatively dense, (semi) erect yellow hairs, sparse on the blue anteromedian area; two lateral white microtrichiose stripes reaching the posterior end of scutum, two submedian microtrichiose stripes extending close after the transverse suture (occassionally almost absent) and more or less visible microtrichia on transverse suture, some specimens with a little trace of median microtrichiose stripe. Supra-alar setae usually black, inserted on enlarged tuberculate alveoli. Proepimeron covered with dense microtrichia and short, sparse, yellow setae. Anepisternum, anterior anepimeron, posterodorsal and ventral part of katepisternum, metasternum covered with long, yellow hairs. Microtrichia reduced or missed on median part of anepimeron, and a large spot on katepimeron (barrette). Scutellum black, with yellow rim; setosity of long yellow setae. Mediotergite mostly shiny, only median $0.25-0.33$ of width sparsely covered with microtrichia.

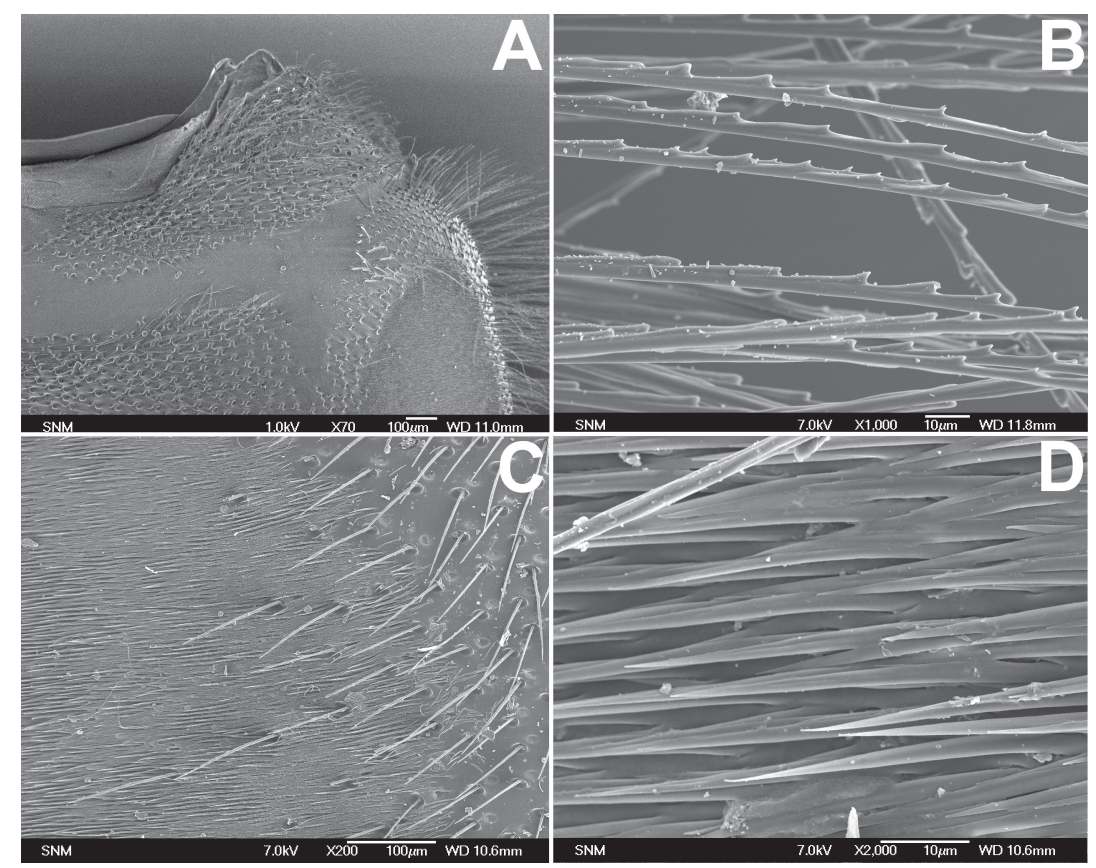

Fig. 9. Megatrigon argenteus (Walker, 1852) comb. nov., tergites, ô (SEM). A. Tergite 2, anterior corner. B. Tergite 4, setae. C. Tergite 3, silver spot. D. Tergite 3, enlarged microtrichia of silver spot. 
WiNG. Membrane slightly brown infuscated, with brown veins and dark, dense microtrichia; at least proximal half of cell br largely without microtrichia; setae on costagium black; halter with yellow pedicel and capitulum.

LEGS. Brown, except light brown-orange on following parts: trochanters (more or less), proximal and distal part of pro- and mesofemur, large part of pro- and mesotibia (except weak submedian dark ring), proximal half and apex of metatibia, pro- (sometimes tarsomere 1 darkened dorsally) and mesotarsus and ventral surface of metatarsus (sometimes also tarsomeres 2-5). Hairs on legs predominately light yellow, long, except some short black setae on anterior and dorsal part of pro- and mesofemur, darkened setae on antero-ventral part of mesotibia and tarsi dorsally (especially metatarsus). White microtrichia distinct on pro- and mesofemur (very dense posteriorly, more inconspicuous on remaining parts), proand mesotibia dorsally, proximal 0.33 of metatibia dorsally (i.e., reduced compared with other species).

ABdomen (Figs 1A, 7A, 9). Cuticle black, except more or less orange translucent areas on tergites $2+3$ covered by dense silvery reflecting microtrichia ('silver spots'); broad (tergite 2 is 1.9-2.4, tergite 3 is $2.2-3.5 \times$ as wide as long); silver spots on tergites $2+3$ large, almost reaching the corners, tapering towards middle of tergite; distance between silver spots on tergite 2 relatively large, $0.2-0.25 \times$ width of tergite; in tergite 3 small, $0.11 \times$ width of tergite; tergite 4 usually with small white non-reflecting microtrichiose spots in median part; tergites light yellow setose, except large area of silver spots without setae, and short black setae on tergite 2 posteriorly, black cuticle of tergite 3 , anteromedially and below microtrichiose spots on tergite 4 mixed with yellow setae. Sternites brown, densly microtrichiose, covered with long light yellow hairs of more or less even length.

Male genitalia (Figs 10A, 11A, 12A, 13A-C). Cerci relatively large, shaped as one quarter of a circle. Median surstyle covered with relatively narrow, longitudinal stripe of microtrichia interiorly; deeply hollowed posteriorly towards posterior surstyle; with inner, acute accessory lobe; ventral margin more or less straight. Posterior surstyle with hooked process recurved in the direction of median surstyle and at the base with external, long setose, bump. Base of epandrium as high as long. Hypandrium sickleshaped, with rather wide distal part, tapering towards apex; base wide, without deep groove.

PuPARIUM (Fig. 14; n=6). Integument rough, dull brown. Dorsally, two pupal spiracles (Fig. 14A:x) project from the middle of the operculum, widely separated by a distance of $4 \times$ their length. These processes are conical structures, $\approx 0,04 \mathrm{~mm}$ long, pointed apically and with numerous disc-shaped tubercles, distributed irregularly on almost the entire surface (Fig. 14B:y), except the apex (Fig. 14C). Each tubercle has 4-8 spiracular openings radially arranged (Fig. 14D). Surface between tubercles and on apex of process rough, reticulate, divided in hexagonal areas. Posterior respiratory process (Fig. 14EF) with total length $\approx 0.23 \mathrm{~mm}$, length between transverse ridge and centre of spiracular plate $(\mathrm{a}): \approx$ $0.30 \mathrm{~mm}$, width at level of the ridge $(\mathrm{b}) \approx 0.45 \mathrm{~mm}, \mathrm{a} / \mathrm{b}=0.67$; short and broad (like in Merodon), wider than long, strongly ridged in proximal half (spiracular plate (Fig. 14E) not studied due to poor condition of specimens, but seems to have four pairs of spiracular openings like in Merodon, not three pairs like in Eumerus). Cephaloskeleton as in Fig. 4G.

\section{Distribution}

Afrotropical - South Africa (Western Cape) (Fig. 15). 


\section{Megatrigon argentifrons sp. nov. urn:Isid:zoobank.org:act:CCF520E8-EBFC-4269-956E-C5E31E92DF3F}

Figs 1B, 2B, 3B, 6A-B, 7B, 10B, 11B, 12B, 15

\section{Diagnosis}

Frons covered with very dense, long, silvery-white setae and microtrichia; on vertex microtrichia present anteriorly, along lateral sides of ocellar triangle and as small, but distinct postocellar spots (Fig. 2B).

\section{Etymology}

The species epithet, which should be treated as a noun in apposition, is derived from the Latin words argentum (= silver) and frons (= forehead), alluding to the dense, silvery microtrichiae that completely cover the frons.

\section{Type material}

\section{Holotype}

SOUTH AFRICA: §̋, Western Cape, Stellenbosch, 8 Oct. 1926, Dr. H. Brauns leg. (RMNH).

\section{Paratypes}

SOUTH AFRICA: 1 đ̃, Western Cape, Uniondale Distr., Bo Kouga, Mar. 1954, museum staff leg. (SAMC); 1 ð̂, KwaZulu-Natal, Bushmans Nek, 2929cc, slopes above hotel, 16 Nov. 1981, J.G.H. Londt leg. (NMSA).

\section{Description}

LeNGTH. Body $7.0 \mathrm{~mm}$, wing $5.0 \mathrm{~mm}$.

HEAD (Figs 2B, 3B). Lateral margins of face more parallel while in M. argenteus comb. nov.slightly divergent; distance between eyes larger than in $M$. argenteus comb. nov., $0.19 \times$ width of head; ocellar triangle eqilateral, without median longitudinal groove; on face microtrichiose stripes along eye margin wide at the level of antennae, but tapering and reduced at lower part, connected with microtrichia below antenna by tiny oblique microtrichiose line; median facial stripe well developed; microtrichia on postocular orbit do not exceed post-ocular ridge.

Thorax. Mesoscutum with two lateral microtrichiose stripes and two submedian microtrichiose stripes ending well behind level of transverse suture; supra-alar setae yellow; microtrichia on mediotergite medially occupied more than 0.5 of width.

WING. Membrane not infuscated, with light brown veins, microtrichia brown; cell br above vena spuria narrowly bare; costagium with yellow setae.

LEGS (Fig. 6A-B). Setae on legs white without black ones; tarsomere 1 of metatarsus darkened dorsally, but without black setae intermingled with light ones.

ABdomen (Figs 1B, 7B). Tergites $2+3$ with large silver spots, touching lateral and posterior margins of tergites, and almost anterior corner; tergite 3 is $2.2 \times$ as wide as long (wider than in the closely related species $M$. natalensis sp. nov.); distance between silver spots on tergite 3 large, $0.22 \times$ as wide as tergite (larger than in M. natalensis sp. nov.); tergites, especially black parts (median part of tergites $2+3$ and whole tergite 4) covered with short, adpressed white-yellow setae (in M. natalensis sp. nov. longer and intensively yellow); silver spots on tergite 3 with reduced setae (contrary to $M$. natalensis sp. nov.); tergite 4 without microtrichiose spots. Male genitalia in Figs 10B, 11B, $12 \mathrm{~B}$.

\section{Distribution}

Afrotropical - South Africa (Western Cape and KwaZulu-Natal) (Fig. 15). 


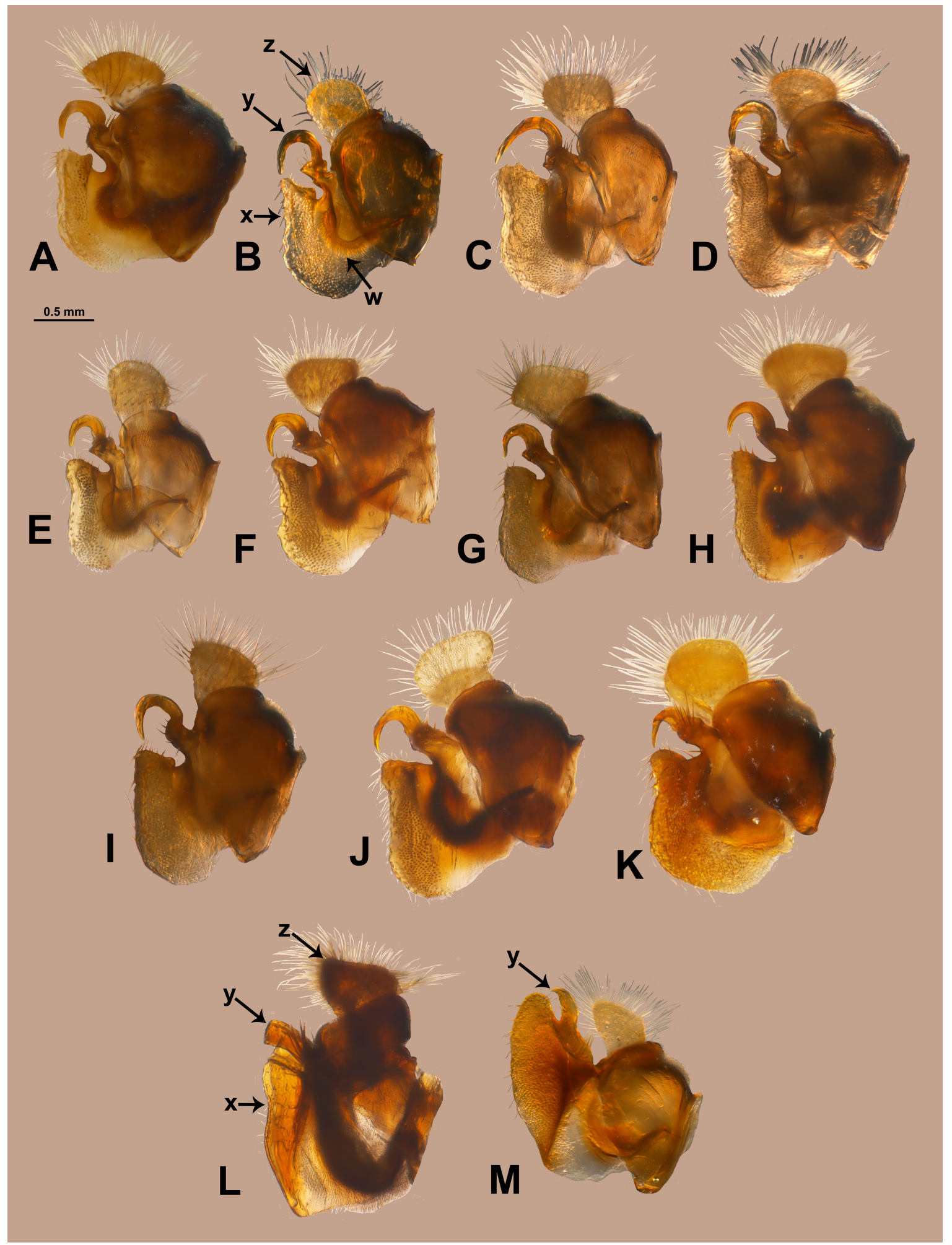

Fig. 10. Megatrigon spp., ठ̊ terminalia, epandrium, left lateral view. A. Megatrigon argenteus (Walker, 1852) comb. nov. B. M. argentifrons sp. nov. C. M. argentimaculatus sp. nov. D. M. magnicornis sp. nov. E. M. natalensis sp. nov. F. M. sexmaculatus sp. nov. G. M. apiformis sp. nov. H. M. cooksoni sp. nov. I. M. immaculatus sp. nov. J. M. ochreatus (Hull, 1964) comb. nov. K. M. tabanoides sp. nov. L. Megatrigon sp. from sexfasciatus group. M. M. nivalis. Symbols: $\mathrm{x}=$ ventral margin of median surstyle; $\mathrm{y}=$ posterior surstyle; $\mathrm{z}=$ cercus; $\mathrm{w}=$ subepandrial sclerite. 


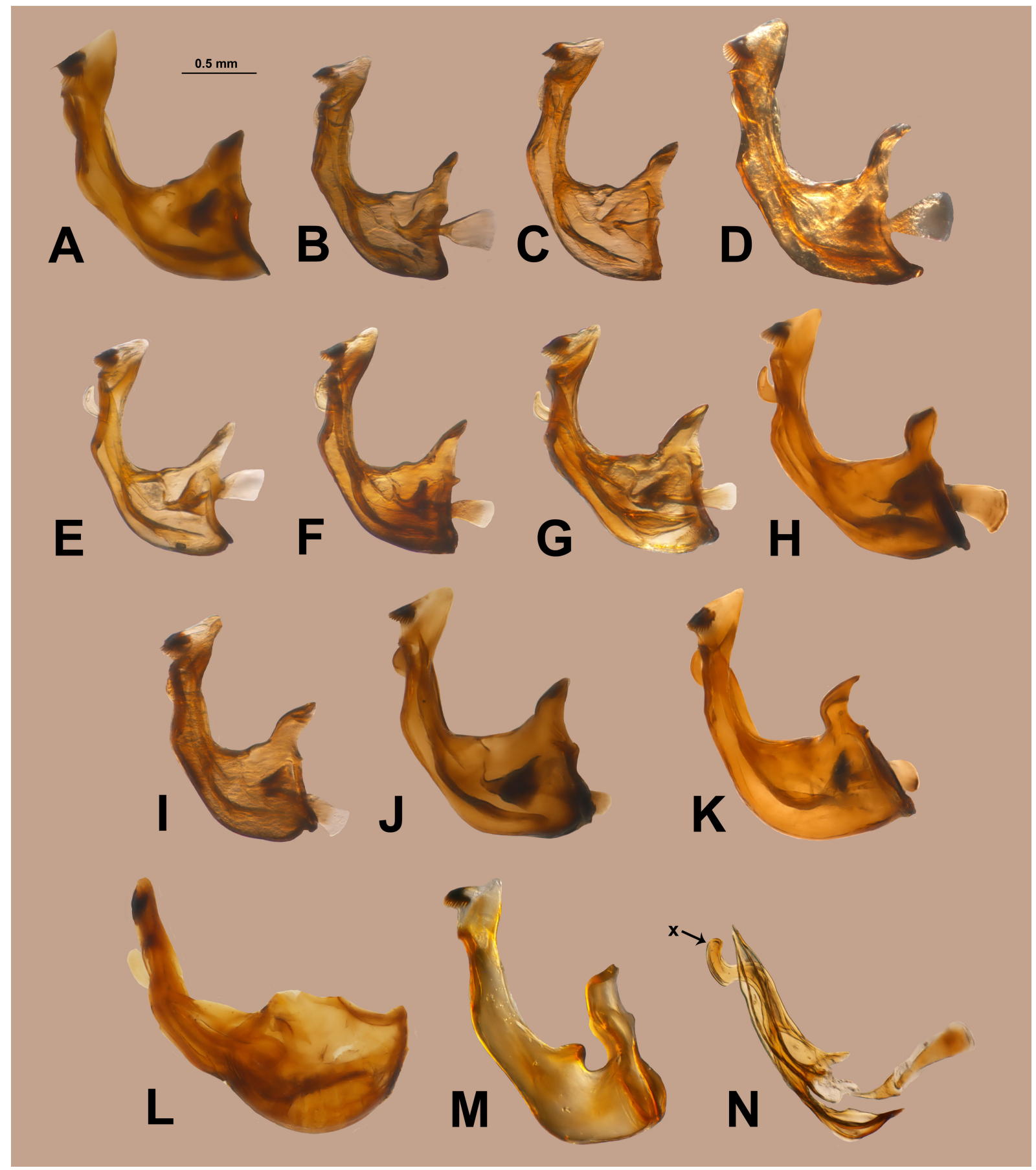

Fig. 11. Megatrigon spp., $\sigma^{\lambda}$ terminalia, hypandrium (A-M) and phallus $(\mathrm{N})$, left lateral view. A. Megatrigon argenteus (Walker, 1852) comb. nov. B. M. argentifrons sp. nov. C. M. argentimaculatus sp. nov. D. M. magnicornis sp. nov. E. M. natalensis sp. nov. F. M. sexmaculatus sp. nov. G. M. apiformis sp. nov. H. M. cooksoni sp. nov. I. M. immaculatus sp. nov. J. M. ochreatus (Hull, 1964) comb. nov. K. M. tabanoides sp. nov. L. M. sp. from sexfasciatus group. M-N. M. nivalis (Hull, 1964) comb. nov. Symbol: $\mathrm{x}=$ hamus. 


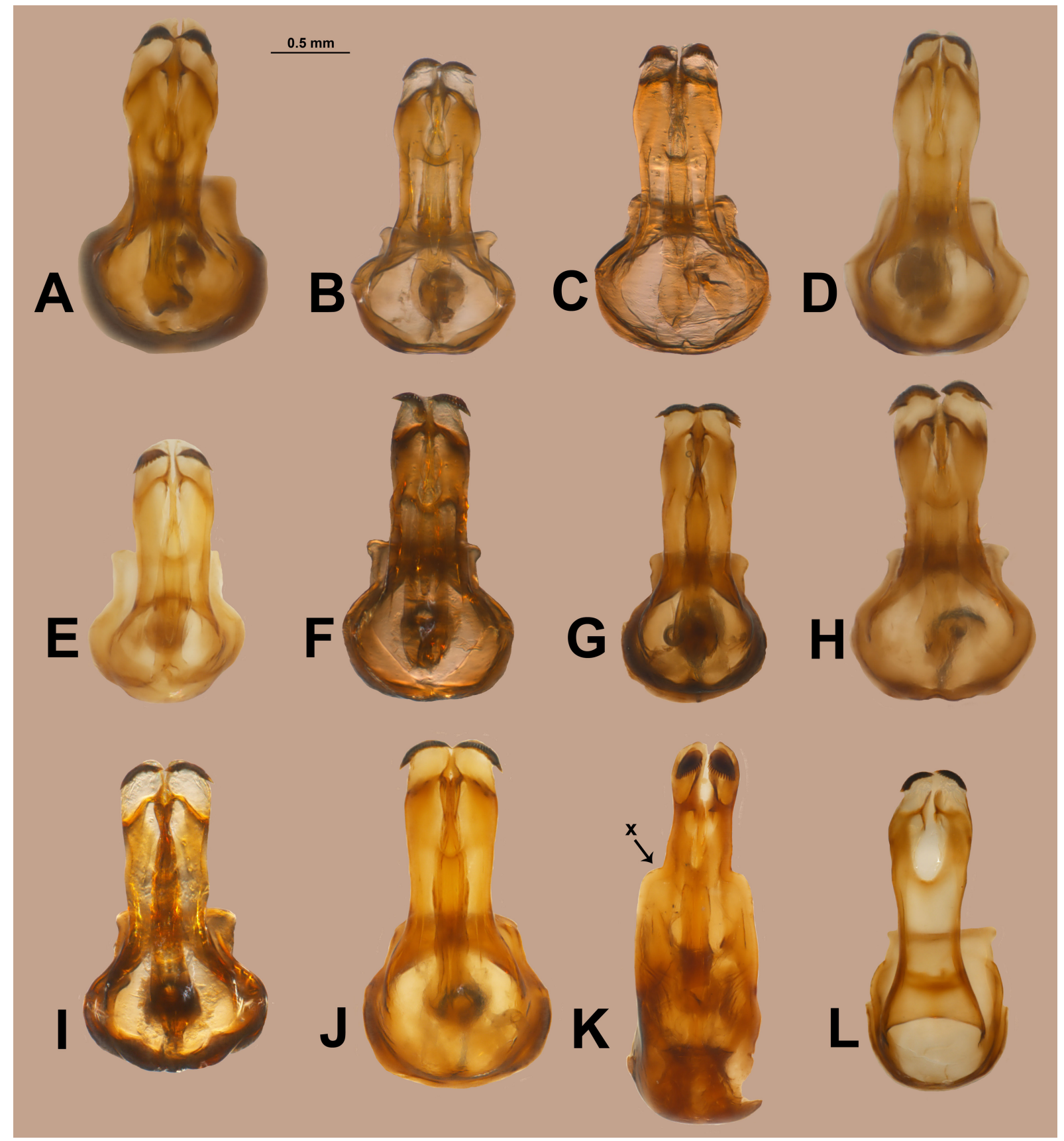

Fig. 12. Megatrigon spp., ô terminalia, hypandrium, ventral view. A. Megatrigon argenteus (Walker, 1852) comb. nov. B. M. argentifrons sp. nov. C. M. argentimaculatus sp. nov. D. M. magnicornis sp. nov. E. M. natalensis sp. nov. F. M. apiformis sp. nov. G. M. cooksoni sp. nov. H. M. immaculatus sp. nov. I. M. ochreatus (Hull, 1964) comb. nov. J. M. tabanoides sp. nov. K. Megatrigon sp. from the sexfasciatus group. L. M. nivalis (Hull, 1964) comb. nov. Symbol: $\mathrm{x}=$ lateral 'shoulders'. 


\section{Megatrigon argentimaculatus sp. nov. urn:1sid:zoobank.org:act:42BB0474-749D-4B47-BF20-C5C9F1C1B84C}

Figs $1 \mathrm{C}, 2 \mathrm{C}, 3 \mathrm{C}, 7 \mathrm{C}, 10 \mathrm{C}, 11 \mathrm{C}, 12 \mathrm{C}, 15$

\section{Diagnosis}

Microtrichia pattern of head (Fig. 2C): Frons shiny anteriorly, microtrichiose posteriorly; between frons and vertex bare transversal line; vertex covered with microtrichia, except ocellar triangle, small central area behind ocellar triangle, short longitudinal line medio-posteriorly and head edge; microtrichia of post-ocular orbit exceeded post-ocular ridge and joined with postocellar microtrichia.

\section{Etymology}

The species epithet, which is formed as an adjective, is derived from the Latin words argentum (= silver) and macula (= spot), alluding to the large silver spots on abdominal tergites $2+3$.

\section{Type material}

\section{Holotype}

SOUTH AFRICA: đ̃, Eastern Cape, Albany Dist., Resolution, 23 Apr. 1928, A. Walton leg. (NMSA).

\section{Description}

LeNGTH. Body $8.0 \mathrm{~mm}$, wing $5.5 \mathrm{~mm}$.

HEAD (Figs 2C, 3C). Microtrichiose stripes on face along eye margin wide and long, extended till tentorial pit and joined with microtrichia below antenna by oblique microtrichiose stripe; distance between eyes a little larger than in $M$. argenteus comb. nov., $0.17 \times$ width of head; ocellar triangle isosceles, without median longitudinal groove; colour of postpedicel (Fig. 3C) dictinctly darker than pedicel.

Thorax. Mesoscutum with two, wide, lateral microtrichiose stripes and two weak submedian microtrichiose stripes starting as triangular markings and ending as small spots at the level of transverse suture; supra-alar setae yellow; median about 0.50 of width of mediotergite covered by microtrichia.

WING. Membrane not infuscated, with yellow veins and microtrichia; cell br above vena spuria completely covered with microtrichia; costagium with yellow setae.

LEGS. Dark submedian ring on pro- and mesotibia weak and visible only ventrally, microtrichia on metatibia distinct in proximal half, dorsally; all tarsi yellow-orange, without shading; all setae of legs light yellow; tarsomere 1 of pro- and metaleg not swollen like in M. argenteus comb. nov.; tarsomere 1 of protarsus anterodorsally without a line of minute black spinules between the yellow trichia.

ABdomen (Figs 1, 7C). Tergites light yellow setose; tergites $2+3$ with very large silver spots, covering most of the tergite's width except for a narrow brown goblet-shaped median part; distance between silver spots on tergite 2 smaller, $0.19 \times$ width of tergite; spots on tergite 3 not tapering towards the middle of tergite, but being more rounded; silver spots on tergites $2+3$ covered with relatively long, dense, adpressed, yellow setae except antero-lateral corner; tergite 4 with two small indistinct microtrichiose spots near to anterior margin. Male genitalia in Figs 10C, 11C, 12C.

\section{Distribution}

Afrotropical - South Africa (Eastern Cape) (Fig. 15). 
Megatrigon magnicornis sp. nov. urn:1sid:zoobank.org:act:DA2E127C-C16A-4ED5-BAAE-5C16FC9DA535

Figs 1D, 2D, 3D, 4A, 6C, 7D, 10D, 11D, 12D, 13D, 15

\section{Diagnosis}

Antennae long, postpedicel very long (Fig. 3D), 1.9-2.2 $\times$ as long as deep, 2.4-2.75 as long as pedicel; tergites $2+3$ (Fig. 7D) with small silver spots (not reaching margins of tergite, except sometimes in tergite 3) largely separated (distance between silver spots on tergites $2+3$ large, $0.45-0.50 \times$ as wide as tergite); silver spots on tergite 3 with scattered black and white setae.

\section{Etymology}

The species epithet, which is formed as an adjective, is derived from the Latin words magnus (= large) and cornus (= horn), alluding to the long antennae.

\section{Type material}

\section{Holotype}

SOUTH AFRICA: §̃, Eastern Cape, Goshen nr. Cathcart, Mar. 1954, museum staff leg. (SAMC).

\section{Paratypes}

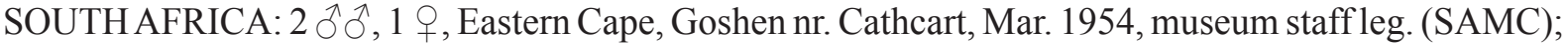
1 §ै, Eastern Cape, Boesmansriviermond, 27-31 Dec. 1985, J. Londt leg. (NMSA); 1 ㅇ, Eastern Cape, Grahamstown, 29 Oct. 1959, D.J. Greathead leg. (BMNH); 1 ㅇ, Eastern Cape, Grahamstown, Apr. 1963, Miss M. Daly \& Miss M. Sole leg. (AMGS).

\section{Description}

LENGTH. Body $10 \mathrm{~mm}$, wing 6.5-7.0 mm.

HeAD (Figs 2D, 3D). Upper part of face across the whole width, at the level and below antennae, completely covered with microtrichia, thereby microtrichiose stripes along eye margin and median facial stripe connected at that level; frons and vertex shiny (only few microtrichia in the middle of frons, anterior and lateral to anterior ocella), without postocellar spots or with very few microtrichia; microtrichia on post-ocular orbit do not exceed post-ocular ridge; length of post-ocular orbit large, $0.11-$ $0.13 \times$ width of head; distance between eyes large, $0.21-0.23$ width of head; ocellar triangle equilateral and without median groove.

Thorax (Fig. 4A). Mesoscutum with two wide, distinct, long, lateral microtrichiose stripes, two long submedian microtrichiose stripes ending far beyond level of transverse suture, and weak prescutellar microtrichia; supra-alar setae yellow; median about 0.5 of width of mediotergite covered by microtrichia.

WING. Membrane not infuscated, veins and microtrichia light brown, cell br above vena spuria almost all covered with microtrichia; costagium with yellow setae.

Legs (Fig. 6C). Setae on legs all yellow; pro- and mesotibia with indistinct dark submedian ring; all tarsi yellow.

ABdomen (Figs 1D, 7D). Tergites $2+3$ and posterior margin of tergite 4 brown-yellow with black alveoli, setae on tergites short, yellow and in some parts black: posterior 0.25 of tergite 2 , submedian and posterior part of tergite 3; tergite 2 medially covered with white microtrichia, tergite 3 with tiny microtrichiose line extended from anterior margin to the centre of tergite, tergite 4 without microtrichiose spots. Male genitalia in Figs 10D, 11D, 12D. 


\section{Distribution}

Afrotropical - South Africa (Eastern Cape) (Fig. 15).

Megatrigon natalensis sp. nov. urn:1sid:zoobank.org:act:38554033-102B-4F8D-BD69-327270AD2A4D

Figs 1E, 2E-F, 3E, 4B, 7E, 10E, 11E, 12E, 15

\section{Diagnosis}

Very similar to M. argentifrons sp. nov. except following characteristics: postocellar spots larger than in argentifrons sp. nov. and almost joined at posteromedian part of vertex (Fig. 2F); on face microtrichiose stripes along eye margin and median facial stripe very reduced, present only as a tiny line but on the whole length; setae on vertex more dense and intensively yellow, and on the frons also yellow, not silvery-white like in M. argentifrons sp. nov. (Fig. 2E); microtrichia on mesoscutum reduced to traces of lateral and submedian stripes (Fig. 4B).

\section{Etymology}

The species epithet, which is formed as a geographical genitive, is derived from the name of the province in South Africa, KwaZulu-Natal, from where the type series of this species originate, i.e., the type locality.

\section{Type material}

\section{Holotype}

SOUTH AFRICA: Ō, KwaZulu-Natal, Bushmans Nek, 2929cc, slopes above hotel, 16 Nov. 1981, J.G.H. Londt leg. (NMSA).

\section{Paratypes}

SOUTH AFRICA: $2 \precsim \hat{\jmath}$, same data as holotype.

\section{Description}

LENGTH. Body $6.5 \mathrm{~mm}$, wing $4.5 \mathrm{~mm}$.

HeAD (Figs 2E, 3E). Distance between eyes relatively large, $0.20-0.21 \times$ width of head, larger than in M. argenteus comb. nov., but similar to M. argentifrons sp. nov.; post-ocular orbit narrow, but slightly wider than in $M$. argenteus comb. nov., $0.10 \times$ width of head; ocellar triangle eqilateral, without median longitudinal groove; postpedicel (Fig. 3E) similar to M. argenteus comb. nov., but pedicel is relatively short (postpedicel $2 \times$ as long as pedicel).

THORAX (Fig. 4B). Microtrichia on mesoscutum reduced so that only traces remain of the submedian and lateral microtrichiose stripes.

WING. Almost entirely covered by microtrichia, only few microtrichia missing in cell br basally, and above vena spuria.

LEGS. Tarsi orange-brown, only tarsomere 1 of metaleg darkened dorsally.

ABDOMEN (Figs 1, 7E). Setae on tergites yellow-gold; abdomen more narrow (tergite 3 is $1.9 \times$ as wide as long) than in M. argenteus comb. nov.; silver spots on tergites $2+3$ are $1.20-1.25$ as long as wide; silver spots on tergite 3 partly covered with setae, especially near to median part of tergites (in M. argentifrons sp. nov. setae are very reduced); tergite 4 without microtrichiose spots. Male genitalia in Figs 10E, 11E, 12E. 


\title{
Distribution
}

Afrotropical - South Africa (KwaZulu-Natal) (Fig. 15).

\author{
Megatrigon sexmaculatus sp. nov. \\ urn:1sid:zoobank.org:act:C2AE7999-2A17-4871-AA30-9614966291FC
}

Figs 1F, 2G, 3F, 7F, 10F, 11F, 15

\section{Diagnosis}

Golden-haired species with three pairs of silver spots on tergites 2-4 (Figs 1F, 7F). Silver spots on tergite 3 completely and densely setose, setae directed towards the lateral margin, i.e., turned ca. $90^{\circ}$ in relation to longitudinal axis. Vertex (Fig. 2G) completely covered with dense, yellow-golden microtrichia except narrow bare stripe along the posterior margin.

\section{Etymology}

The species epithet, which is formed as an adjective, is derived from the Latin words $\operatorname{sex}(=\operatorname{six})$ and macula (= spot), alluding to the three pairs of silver spots on abdominal tergites $2-4$.

\section{Type material}

\section{Holotype}

SOUTH AFRICA: đ, Eastern Cape, Strowan, Grahamstown, 10 Oct. 1967, C. Jacot-Guillarmod leg. (AMGS).

\section{Paratype}

SOUTH AFRICA: 1 §,, Eastern Cape, Hilton, Grahamstown, sandpile, 25 Oct .1977, F.W. Gess leg. (AMGS).

\section{Description}

Length. Body 7.5-8.0 mm, wing 5.5 mm.

HeAd (Figs 2G, 3F). Face and frons similar to $M$. argenteus comb. nov.; ocellar triangle isosceles without groove; length of post-ocular orbit as usual, but a little larger than in $M$. argenteus comb. nov. $0.09-0.10 \times$ width of head; postpedicel (Fig. 3F) larger than in M. argenteus comb. nov., $1.6-1.8 \times$ as long as deep; $2.2 \times$ as long as pedicel.

THORAX. Submedian microtrichia present on mesoscutum only anteriorly as triangular markings and as small spots at the level of transverse suture, besides two distinct, long lateral microtrichiose stripes; supraalar setae yellow; microtrichia on mediotergite covered about 0.4 of width.

WING. Yellow setae on costagium.

LEGs. Setae on legs all light; of tarsi, only tarsomere 1 and to a lesser extent tarsomere 2 of metaleg dorsally darkened.

Abdomen (Figs 1F, 7F). Tergites covered with relatively long, dense yellow-golden setae, without black ones; lateral silver spots on tergites $2-4$ triangular, relatively large: on tergites $2+3$ almost reaching the corners, tapering towards the middle of tergite where they approach each other; spots on tergite 4 anterior, small, widely separated from each other and lateral margin, but touching anterior margin. Male genitalia in Figs 10F, 11F.

\section{Distribution}

Afrotropical - South Africa (Eastern Cape) (Fig. 15). 


\title{
Subgroup 2
}

Male tergites without silver spots, i.e., microtrichiose spots not reflecting, tergites $2+3$ more convex.

\author{
Megatrigon apiformis sp. nov. \\ urn:1sid:zoobank.org:act:F83D697B-489E-4E4C-AE21-BB7A4FCA6C4F \\ Figs $1 \mathrm{G}, 2 \mathrm{H}, 3 \mathrm{G}, 4 \mathrm{C}, 5 \mathrm{~A}, 7 \mathrm{G}, 10 \mathrm{G}, 11 \mathrm{G}, 12 \mathrm{~F}, 16$
}

\section{Diagnosis}

Small, slender, golden-haired species (Fig. 1G); head (Fig. 2H) almost entirely covered by dense, whiteyellow microtrichia except following bare parts: triangular area laterally from median microtrichiose stripe on face, area lateral and above the antennae, posterior margin of the head (in dorsal view); wing (Fig. 5A) completely covered with very dense, white microtrichia; mesoscutum (Fig. 4C) besides lateral microtrichiose stripes, also with long submedian stripes far exceeded the level of transverse suture, indistinct median stripe along the whole length of mesoscutum (can be interrupted) and well-developed prescutellar microtrichia.

\section{Etymology}

The species epithet, which is formed as an adjective, is derived from the Latin words apis (= [honey] bee) and forma (= shape), alluding to the honey bee-like appearance of this species.

\section{Type material}

\section{Holotype}

SOUTH AFRICA: §̊, KwaZulu-Natal, Pietermaritzburg, 12 Oct. 1971, leg. M.E. Irwin (NMSA).

\section{Paratype}

SOUTH AFRICA: 1 §, KwaZulu-Natal, Goskies Farm, Karkloof, 21 Dec. 1983, B.R. Stuckenberg leg. (NMSA).

\section{Description}

LeNGTH. Body $7.5 \mathrm{~mm}$, wing $5.8 \mathrm{~mm}$.

HeAd (Figs 2H, 3G). Distance between eyes, $0.16-0.17 \times$ width of head; post-ocular orbit wider, the width of post-ocular orbit dorsally $0.13-0.14$ as wide as head; ocellar triangle isosceles, without median longitudinal groove; postpedicel (Fig. 3G) almost rounded, 1.2-1.3 $\times$ as long as deep, 1.6-1.7 $\times$ as long as pedicel; supra-alar setae yellow.

Thorax (Fig. 4C). Microtrichia on mediotergite covered about one third of width.

WING (Fig. 5A). Setae on costagium yellow; wing veins mostly yellow, but darker distally.

LEGS. Setae on legs yellow; only apex of pro- and mesofemur lighter, not also the base; of tarsi, only tarsomere 1 of metaleg darkened dorsally; microtrichia on metatibia dorsally relatively short like in $M$. argenteus comb. nov.

AbDomen (Fig. 7G). Relatively narrow, tergite 2 is $1.8 \times$ and tergite 3 is $2 \times$ as wide as long; tergites with a golden lustre, long, dense, golden setose; tergites $2-4$ with transversal, yellow-white microtrichiose fasciae connected in the middle; fasciae on tergites $2+3$ oblique and reaching lateral margins, tergite 4 with horizontal fasciae, widely separated from lateral margin; tergite 4 with wide microtrichiose posterior margin and one or two pairs of depressions; indistinct white microtrichia present anteromedially on 
tergites $2-4$, more developed on tergite 2 , but on tergites $3+4$ connected with fasciae along the median line. Male genitalia in Figs 10G, 11G, 12F.

\section{Distribution}

Afrotropical - South Africa (KwaZulu-Natal) (Fig. 16).

Megatrigon cooksoni sp. nov. urn:1sid:zoobank.org:act:3E26326F-E773-4EAC-8AC0-97B5697434463

Figs $1 \mathrm{H}, 2 \mathrm{I}, 3 \mathrm{H}, 5 \mathrm{~B}, 7 \mathrm{H}, 10 \mathrm{H}, 11 \mathrm{H}, 12 \mathrm{G}, 16$

\section{Diagnosis}

Black species with white, connected microtrichiose fasciae on tergites (Figs $1 \mathrm{H}, 7 \mathrm{H}$ ) and bicoloured wing resulting from dense microtrichia, white in proximal 0.6 and brown in distal 0.4 (Fig. 5B). Frons shiny; vertex and post-ocular orbit white microtrichiose except area between posterior ocelli, medioposterior part, spots at eye corner and posterior dorsal margin of head (Fig. 2I).

\section{Etymology}

The species epithet, which is formed as a male genitive, is derived from the personal name of the collector, Mr. Daniel Montague Cookson.

\section{Type material}

\section{Holotype}

ZIMBABWE: đ̂, N. Vumba, 6,000ft, 16 Jan. 1966, D. Cookson leg. (NMSA).

\section{Paratypes}

ZIMBABWE: $2 \precsim \hat{\jmath}$, same locality as holotype, 21 Feb. 1965, D. Cookson leg. (NMSA).

\section{Description}

LeNGTH. Body $10.0 \mathrm{~mm}$, wing $7.0 \mathrm{~mm}$.

Head (Figs 2I, 3H). Distance between eyes, $0.17 \times$ width of head; width of vertical triangle $0.26-0.29 \times$ width of head; postocular orbit wider, the width of postocular orbit dorsally $0.13 \times$ as wide as head; ocellar triangle equilateral, without median longitudinal groove; microtrichia on face well developed and similar to M. ochreatus comb. nov.: white microtrichiose stripes along eye margin distinct, connected with wide median microtrichiose facial stripe below antennae by narrow oblique stripe.

Thorax. Mesoscutum with lateral microtrichiose stripes wide and long, posteriorly connected with scarce prescutellar microtrichia; indistinct submedian stripes ending at conspicuous microtrichiose spots on transverse sutures; traces of median stripe ending near the level of transverse suture; supra-alar setae yellow; mediotergite almost entirely covered by microtrichia.

WING (Fig. 5B). Setae on costagium white; veins brown; capitulum brown.

LEGS. Only apex of pro- and mesofemur pale, not the base; tarsi yellow, only tarsomere 1 of metaleg brown dorsally; metatibia dorsally with white microtrichia in proximal half that reach the scar.

Abdomen (Figs 1H, 7H). Tergites 2-4 black with white transversal microtrichiose fasciae connected medially, on tergites $2+3$ touching lateral margins, while on tergite 4 widely separated from them; fasciae on tergites $2+3$ oblique and on tergite 4 more straight; tergite 2 with inconspicuous white microtrichia anteromedially, tergite 4 with wide microtrichiose posterior margin. Male genitalia in Figs 10H, 11H, 12G. 


\section{Distribution}

Afrotropical - Zimbabwe (Fig. 16). Megatrigon immaculatus sp. nov.
urn:lsid:zoobank.org:act:247A01B0-3787-429C-AD8E-0DAFFEADE8FC

Figs 1I, 2J, 3I, 7I, 10I, 11I, 12H, 16

\section{Diagnosis}

Dark brown-black species with almost no markings and blue lustre, covered with short white hairs (Fig. 1I); face shiny, apart from white microtrichiose area below antennae, only traces of usual microtrichia pattern present; frons and vertex shiny without microtrichia, both inflated and without border between them, cuticle smooth without indistinct alveoli (Fig. 2J); tergites dark brown without any markings (except in a female tentatively assigned to this species with three pairs of weak, white, oblique microtrichiose fasciae on tergites 2-4) covered with white setae (Fig. 7I); tergite 4 with two small depressions on posterior half.

\section{Etymology}

The species epithet, which is formed as an adjective, is derived from the Latin negation prefix in(= "not"; here in the assimilated form im-), and macula (= spot), alluding to the lack of spots or other distinct markings on the abdominal tergites.

\section{Type material}

\section{Holotype}

SOUTH AFRICA: §̊̄, Eastern Cape, Queenstown, 28 Aug. 1962, A. Busse leg. (AMGS).

\section{Additional material}

SOUTH AFRICA: $1 \delta 1$, Western Cape, Uniondale District, Bo Kouga, Mar. 1954, museum staff leg. (SAMC). These specimens are not designated as paratypes, as they differ in small details from the type of M. immaculatus sp. nov. and for that reason may not be conspecific. More material is needed to explore the significance of the observed differences.

\section{Description}

LENGTH. Body $8.0 \mathrm{~mm}$, wing $5.5 \mathrm{~mm}$.

HeAd (Figs 2J, 3I). Distance between eyes larger than in M. argenteus comb. nov., $0.23 \times$ width of head; postocular orbit slightly wider, the width of postocular orbit dorsally $0.11 \times$ as wide as head; ocellar triangle equilateral, without median longitudinal groove.

Thorax. Mesoscutum with lateral microtrichiose stripes on notopleuron shifted medially (can be reduced), submedian stripes ended at the level of transverse suture; bare area on katepisternum and anterior anepimeron are larger than usual.

LeGs. Almost completely dark (pro- and mesotarsus slightly darkened dorsally) except pale ends of pro- and mesofemur and tibia and ventral surface of tarsi; legs entirely white setose; metafemur with blue-violet lustre anterodorsally.

WiNG. Membrane less infuscated than in M. argenteus comb. nov.; costagium with yellow setae; capitulum brown. 
Abdomen (Fig. 7I). Male genitalia in Figs 10I, 11I, 12H.

\section{Distribution}

Afrotropical - South Africa (Eastern and Western Cape) (Fig. 16).

Megatrigon ochreatus (Hull, 1964) comb. nov.

Figs 1J, 2K, 3J, 7J, 10J, 11J, 12I, 16

Eumerus ochreatus Hull, 1964: 493. South Africa, Eastern Cape, Katberg.

\section{Diagnosis}

Frons and vertex shiny (Fig. 2K), almost without microtrichia (like in M. immaculatus sp. nov., M. magnicornis sp. nov. and M. tabanoides sp. nov.); tergites 2-4 with pairs of white microtrichiose fasciae, covered by yellow setae (Fig. 7J): tergite 2 with two small spots at posterolateral corners and indistinct microtrichia anteromedially, tergite 3 with two short, widely separated, postero-lateral stripes reaching lateral margins and tergite 4 with two large stripes tapering and almost connected in the middle, but not reaching lateral margins.

\section{Type material}

\section{Holotype}

SOUTH AFRICA: đ̊, Eastern Cape, Katberg, 1-10 Feb. 1933, R.E. Turner leg. (BMNH).

\section{Paratypes}

SOUTH AFRICA: 1 ðૈ, KwaZulu-Natal, Royal Natal Nat. Park, 18 Mar. 1989, J.G.H. Londt leg. (NMSA); 1 §, Western Cape, Worcester Karoo Gardens, 17 Oct. 1970, H.V. Daly leg. (CAS).

\section{Description}

LeNGTH. Body $10.0 \mathrm{~mm}$, wing $7.5 \mathrm{~mm}$.

HEAD (Figs 2K, 3J). Face largely microtrichiose: microtrichiose stripes along eye margins long, wide, especially at the level below antennae where joined median facial stripe and narrow oblique stripe; face and gena wider than in M. argenteus comb. nov., gena $1.5 \times$ as wide as postpedicel (in M. argenteus comb. nov. gena and postpedicel of equal width); distance between eyes larger than in M. argenteus comb. nov., $0.19 \times$ width of head; postocular orbit wider than in $M$. argenteus comb. nov., the width of postocular orbit dorsally $0.13 \times$ width of head; postpedicel longer than in M. argenteus comb. nov., $1.7 \times$ as long as deep; $1.7 \times$ as long as pedicel; ocellar triangle equilateral without median longitudinal groove.

THorax. Mesoscutum with lateral microtrichiose stripes and traces of prescutellar microtrichia; supraalar setae yellow; mediotergite mostly covered with microtrichia.

WiNG. Membrane irregulary yellow-brown infuscated, densely covered with microtrichia that is mainly yellow-brown, except white microtrichia along the posterior edge and wing base; costagium with yellow setae.

LeGs. Setae yellow; all tarsi yellow, metatibia almost entirely dark, with white microtrichia in proximal half dorsally that reach the scar.

Abdomen (Figs 1J, 7J). Narrower than in M. argenteus comb. nov. (tergite 3 is $1.8 \times$ as wide as long); tergites yellow setose, except black short hairs in posterior part of tergite 2 , anterior and posterior 0.33 of tergite 3, and anteriorly of tergite 4. Male genitalia in Figs 10J, 11J, 12I. 


\title{
Distribution
}

Afrotropical - South Africa (Eastern and Western Cape, KwaZulu-Natal) (Fig. 16).

\author{
Megatrigon tabanoides sp. nov. \\ urn:1sid:zoobank.org:act:AF0AED98-F365-434F-A0FF-EA337D9374D7
}

Figs $1 \mathrm{~K}, 2 \mathrm{~L}, 3 \mathrm{~K}, 5 \mathrm{C}, 7 \mathrm{~K}, 10 \mathrm{~K}, 11 \mathrm{~K}, 12 \mathrm{~J}, 16$

\section{Diagnosis}

Black, large species, with white microtrichiose stripes on tergites (Figs 1H, 7K); wing membrane brown along the veins (Fig. 5C); alula bare of microtrichia at posterior margin; all tibiae orange without dark ring; tarsomeres 4-5 black dorsally (rest of tarsomeres can be shaded); only species with intraalar microtrichia on mesoscutum; postsutural pilosity of mesoscutum mainly black.

\section{Etymology}

The species epithet, which is formed as an adjective, is derived from the Latin word tabanus (= horse fly), alluding to the resemblance of this species to a horse fly of the genus Tabanus Linnaeus.

\section{Type material}

\section{Holotype}

SOUTH AFRICA: §̊, Western Cape, 5 km E of Lambert's Bay, westcoast strandveld, 31 Aug. 1981, J. Londt, L. Schoeman \& B. Stuckenberg leg. (NMSA).

\section{Paratypes}

SOUTH AFRICA: 1 ठ, Northern Cape, Bowesdorp, Sep. 1941, museum staff leg. (SAMC); 1 ठ, Northern Cape, $16 \mathrm{~km} \mathrm{~S}$ of Steinkopf, 1000 m, 31 Aug. 1989, Stuckenberg, Londt \& Crosser leg.

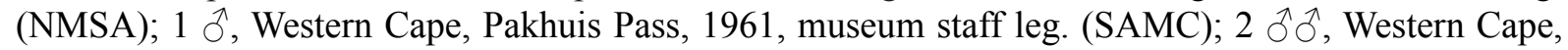
$5 \mathrm{~km}$ E of Lambert's Bay, 31 Aug. 1981, Londt, Schoeman \& Stuckenberg leg. (NMSA); 2 ô $\widehat{\jmath}$, Western

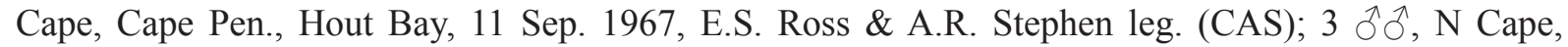
Hantams Nat. Botanical Garden Neuwoudville, Rocky ridge, 750 m, 31 ${ }^{\circ} 24^{\prime} 49^{\prime \prime}$ S, 1909'35" S, 11 Sep. 2012, J. \& A. Londt leg. (NMSA).

\section{Description}

LeNGTH. Body $12.0 \mathrm{~mm}$, wing 7.5-8.0 mm.

HeAD (Figs 2L, 3K). Distance between eyes, $0.16-0.17$ width of head; the width of post-ocular orbit dorsally a little larger than in $M$. argenteus comb. nov. $0.10-0.11 \times$ width of head; microtrichia on head reduced: on face traces of microtrichia along eye margin, wide microtrichiose area below antennae continuing as tiny medial facial stripe; frons and vertex shiny; microtrichia on postocular orbit do not exceed postocular ridge.

THORAX. Lateral microtrichiose stripes on mesoscutum missing, submedian stripes indistinct ending as a spot at the level of transverse suture, conspicuous intraalar microtrichiose stripe.

WING (Fig. 5C). Capitulum brown.

LEGS. Pro- and mesofemur partly black, but orange at base, apex, and anteriorly in distal half; metafemur mainly black with blue or violet luster, but orange-brown at base and in some specimens also ventrally; hairs on legs mainly white with more or less numerous short black setae on all femora and tibiae, black long posteroapical tuft on metatibia, tarsi dorsally predominately covered by black setae. 
ABdomen (Figs $1 \mathrm{~K}, 7 \mathrm{~K}$ ). tergites $2-4$ black, with oblique white microtrichiose fasciae almost connected in the middle; triangular on tergite 2 and touching posterior corner, on tergites $3+4$ separated from lateral margins (or barely touching on tergite 3 in some specimens). Male genitalia in Figs 10K, 11K, 12J.

\section{Distribution}

Afrotropical - South Africa (Northern and Western Cape) (Fig. 16).

\section{sexfasciatus group}

\section{Diagnosis}

Katepisternum with a posterodorsal and a small posteroventral pile patch, with or without a few short setae below the dorsal patch. The bare, flat posterior margin of tergite 1 (almost) entirely without microtrichia. Base of wing entirely microtrichiose or at most with small bare areas in cells br, bm, or cup. Anepisternal setae saw-like. Tarsomere 1 of protarsus anterodorsally without black spinules between the yellow setae. $\sigma^{\lambda}$ : Sternite 4 with inflated caudal lobes, partly without microtrichia, and with a small accessory lobe close to the base of the lobes. Genital pouch large, more than half as wide as abdominal segment 4 at anterior margin. Posterior surstyle lobe (Fig. 13E:y, F:y) straight, without hook, directed medially. Median surstyle lobe (Fig. 13E, F:w) setose along posterior half of ventral margin, on median surface without accessory lobe, without microtrichia, its posterior end extended, forming a wide rounded lobe directed posteromedially. Cerci (Fig. 10L:z) with pointed apex, with sclerotized and setose ventral surface. Subepandrial sclerite strongly curved, its anterior part almost parallel to the posterior part, a complete sclerotized bridge at its anterior end, the posterior part microtrichiose on full length, without a bulging 'pad' (Fig. 13G:z). Hypandrium (Figs 11L, 12K) with a very wide base and lateral 'shoulders' between the wide proximal and the narrower distal part, apex slightly produced beyond ctenidium and blunt. Ejaculatory apodeme large. $q$ : tergite 5 and sternite 5 with posteriorly directed setae, ovipositor with moderately thick setae, without tooth.

\section{Included species}

Megatrigon flavimarginatus (Hull, 1964) comb. nov. (Eumerus; holotype in BMNH, examined).

Megatrigon jacobi (Hervé-Bazin, 1913) comb. nov. (Eumerus; holotype in MRAC, examined).

= Eumerus connexus Hull, 1964, syn. nov. (holotype in BMNH, examined).

Megatrigon sexfasciatus Johnson, 1898 (holotype in BMNH, examined).

Due to the lack of sufficient material, the species of the sexfasciatus group are not (re)described in the present account. Megatrigon jacobi comb. nov. (Figs 1L, 2M, 3L, 7L, 13E) is a distinctive species readily recognised by the reduced mouthparts and related features of the lower parts of the head (similar to Merodon bombiformis Hull, 1944). The identity of $M$. sexfasciatus remains obscure. The material that has been available for the present study consists of males of several species that in external characters are very similar to the female holotype of $M$. sexfasciatus. At present we cannot assign any of the available males to the nominal taxon $M$. sexfasciatus. There are several 'morphs' similar to the type of M. flavimarginatus comb. nov. in the available material. However, as most of these are represented by singletons, we are unable to assess the significance of the observed, often slight, morphological differences and for that reason we refrain from describing them here. More material in good condition is needed to uncover the species diversity in the sexfasciatus group, but we expect that a good number of distinct species will be discovered.

\section{Key to species of Megatrigon}

The currently known species are probably a fraction only of the species actually in existence, and users of the key should expect to encounter species that are not included. The key should be used mainly as 
a step in the identification process, and proper identification requires comparisons with the diagnoses and descriptions, including a thorough study of the terminalia. As the identification of females is still unresolved and/or the assignment to the corresponding males is uncertain, the key can be used for males only (except for the very distinct female of $M$. nivalis comb. nov.).

1. Katepisternum posteriorly setose over (almost) full width. Wing base extensively bare of microtrichia, esp. large parts of cells c, $\mathrm{r}_{1}, \mathrm{br}, \mathrm{bm}$, and cup. The bare flat posterior margin of tergite 1 extensively microtrichiose. Thoracic setae not feathered but thickened and strongly glistening. $\delta$ terminalia with posterior surstyle lobe directed posteriorly, with a small hook at apex (Fig. 10M:y). o tergite 5 and sternite 5 with anteriorly directed setae (Fig. 8A-B), ovipositor with a subapical dorsal tooth (Fig. 8C) .......................nivalis group: M. nivalis (Hull, 1964) comb. nov. (Fig. 1M)

- Katepisternum either without setae between the dorsal and the ventral pile patches or with a few short setae below the dorsal patch. Wings either entirely microtrichiose or with small areas in cells br, bm, and/or cup bare of microtrichia. The bare flat posterior margin of tergite 1 (almost) bare of microtrichia. Thoracic setae serrate. $\hat{\jmath}$ terminalia with posterior surstyle lobe directed medially (Fig. 13B, F:y). + tergite 5 and sternite 5 with posteriorly directed setae, ovipositor without a tooth $\ldots . . .2$

2. Posterior surstyle lobe straight, without hook (Fig. 13E:y, F:y). Sternite 4 with inflated caudal lobes, each of which bears a small process on their median margin (usually visible only when the terminalia are extended), and with some part bare of microtrichia sexfasciatus group [not treated here at the species level]

- Posterior surstyle lobe forming a strong twisted hook(Fig. 13A:y, B:y). Sternite 4 with flat caudal lobes, without process at median margin, and entirely covered by microtrichia .... 3 argenteusgroup

3. Tergites $2+3$ with silver spots (Fig. 7A-F), i.e., areas densely covered by adpressed reflecting white microtrichia. These spots cover the lateral part of the tergite for more than three quarters the length of the tergite ...4

- Tergites $2+3$ without silver spots (Fig. 7G-K). Non-reflecting fasciae or spots of microtrichia are present, their maximum length less than half the length of the tergite, or all tergites without any markings

4. Costagial setae black. Ocellar triangle with a longitudinal groove. Mesofemur anteriorly black setose. Metatibia in proximal half dorsally with reduced microtrichia, not reaching scar. Tergite 4 with a pair of isolated submedian microtrichiose spots (Fig. 7A)

M. argenteus (Walker, 1852) comb. nov. (Fig. 1A)

- Costagial setae yellow. Ocellar triangle without groove. Mesofemur without black setae. Metatibia in proximal half dorsally with a microtrichiose stripe that extends to the scar. Tergite 4 either without microtrichiose spots or present (M. sexmaculatus sp. nov.) anterolaterally......5

5. Tergite 4 with silver spots (Fig. 7F). Silver spots on tergite 3 completely and densely setose, setae directed towards the lateral margin, i.e., turned ca. $90^{\circ}$ in relation to longitudinal axis. Vertex entirely microtrichiose except for a narrow stripe along the posterior margin (Fig. 2G) .....

M. sexmaculatus sp. nov. (Fig. 1F)

- Tergite 4 without silver spots. Silver spots on tergite 3 for a large part without setae or (some M. magnicornis sp. nov.) with scattered setae, setae turned to the side for ca $45^{\circ}$. At least ocellar triangle partly bare of microtrichia

6. Postpedicel elongated (Fig. 3D). Vertex almost bare of microtrichia (Fig. 2D). Silver spots on tergite 3 widely separated, their distance exceeds the length of the tergite, narrowly separated from anterior and posterior margins (Fig. 7D). Tergite 3 with extensive areas with black setae 
- Postpedicel normal. Vertex in front of anterior ocellus entirely densely microtrichiose. Silver spots on tergite 3 narrowly separated, their distance less than half the length of the tergite, covering whole length of tergite. Tergite 3 with or without a few scattered black setae ................... 7

7. Distance between eyes $0.17 \times$ width of head, ocellar triangle isosceles (Fig. 2C). Larger species, body length about $8 \mathrm{~mm}$ M. argentimaculatus sp. nov. (Fig. 1C)

- Distance between eyes larger, ocellar triangle equilateral (as in Fig. 2F). Smaller species, body length $6.5-7.0 \mathrm{~mm}$ 8 (as in Fig. 1B, E)

8. Postocellar spot small, separated for about the distance between posterior ocelli (Fig. 2B). Median apex of the silver spot on tergite 2 near middle of tergite (Fig. 7B). Mesonotum with welldeveloped submedian and lateral (notopleuron, supraalar area) microtrichiose stripes .........

M. argentifrons sp. nov. (Fig. 1B)

- Postocellar spot large, almost confluent (Fig. 2E, F). Median apex of the silver spot on tergite 2 close to posterior margin of tergite (Fig. 7E). Mesonotum with traces only of the submedian and lateral microtrichiose stripes (Fig. 4B)

M. natalensis sp. nov. (Fig. 1E)
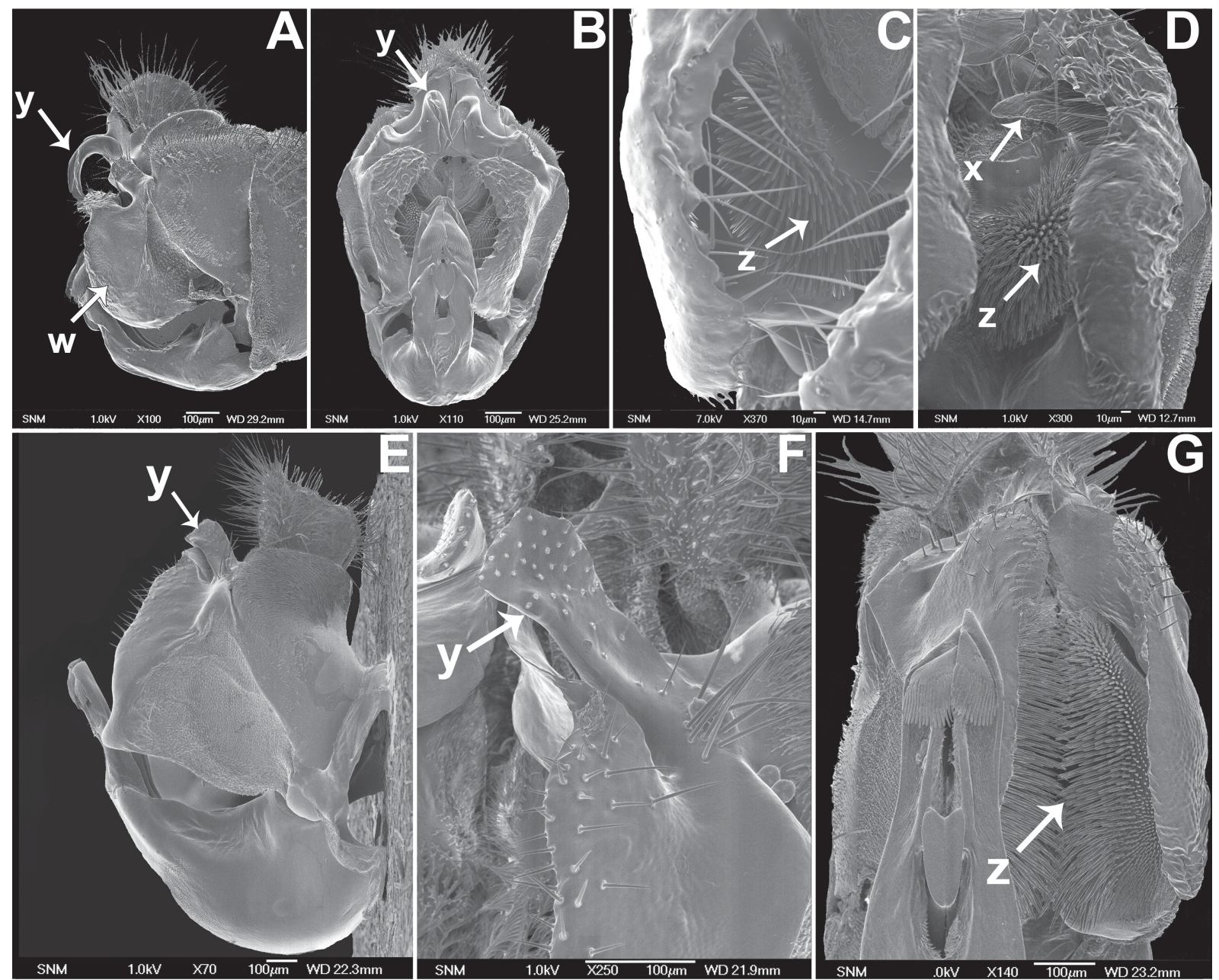

Fig. 13. Megatrigon spp., ô genitalia, lateral (A, F) and ventral (B-E, G) view (SEM). A-C. Megatrigon argenteus (Walker, 1852) comb. nov. D. M. magnicornis sp. nov. E. M. jacobi (Hervé-Bazin, 1913) comb. nov. F-G. Megatrigon sp. from the sexfasciatus group. Symbols: $\mathrm{w}=$ median surstyle; $\mathrm{x}=$ inner accessory lobe of median surstyle; $\mathrm{y}=$ posterior surstyle; $\mathrm{z}=$ subepandrial sclerite. 


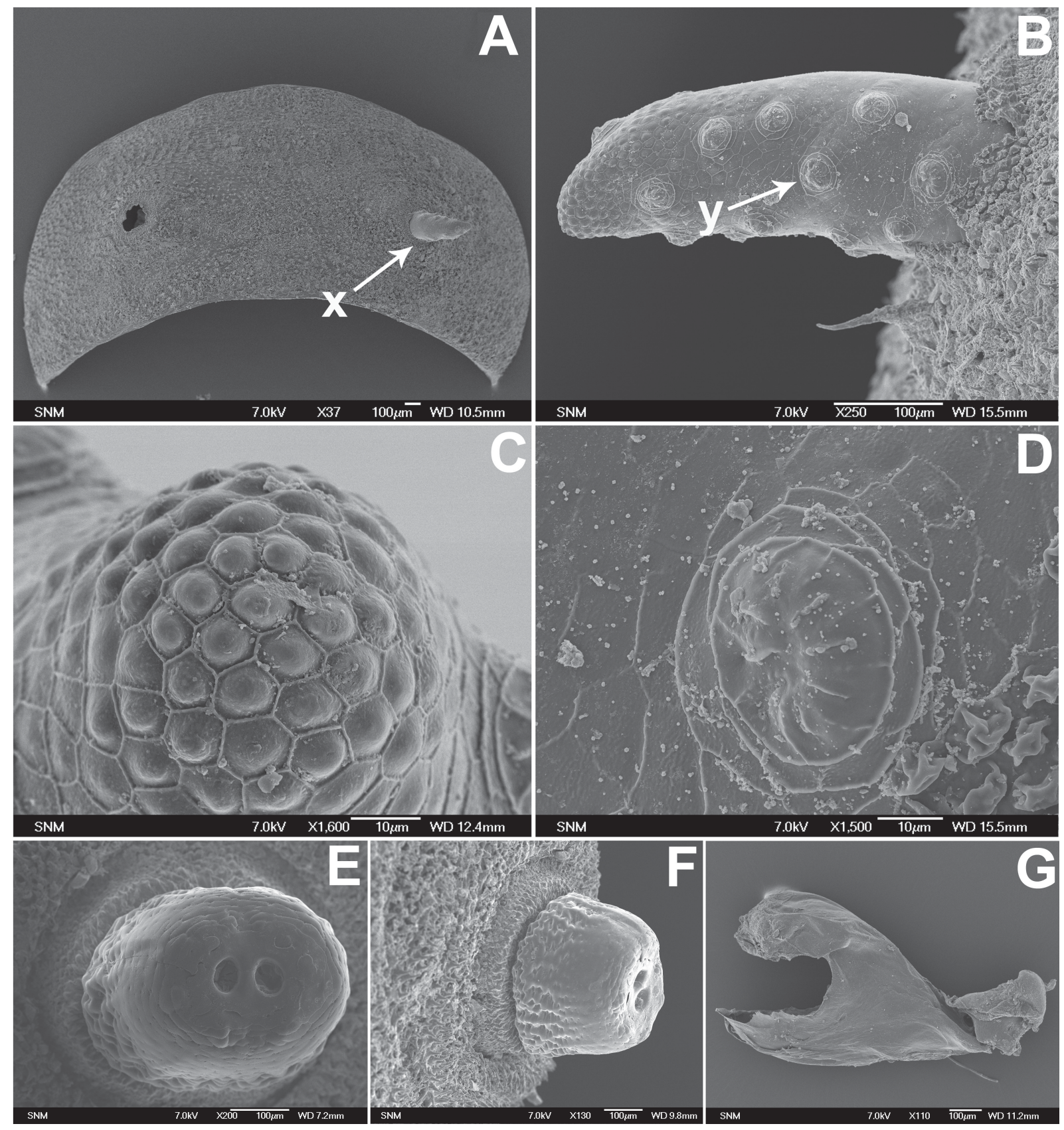

Fig. 14. Megatrigon argenteus (Walker, 1852) comb. nov., puparium (SEM). A. Operculum with right pupal spiracle (arrow), B. Pupal spiracle in lateral view (arrow points at tubercle with spiracular openings). C. Apex of pupal spiracle. D. Detail of tubercle with spiracular openings borne on pupal spiracle. E. Spiracular plate on the posterior respiratory process in polar view. F. Posterior respiratory process. G. Cephaloskeleton, lateral view. Symbols: $\mathrm{x}=$ pupal spiracle; $\mathrm{y}=$ spiracular tubercle. 
9. Tergites without microtrichiose fasciae or spots (Fig. 7I). Distance between eyes big, frons and vertex with smooth surface (setae with simple alveoli, i.e., without tubercles), without microtrichia (Fig. 2J)

M. immaculatus sp. nov. (Fig. 1I)

- At least tergites $2+3$ with microtrichiose fasciae or spots (as in Fig. 7K). Distance between eyes narrower, frons and vertex with rough surface (setae with tuberculate alveoli), with microtrichiose

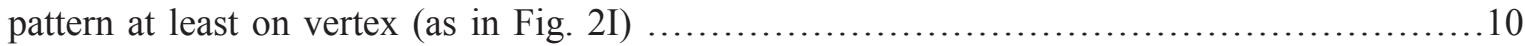

10. Postsutural pilosity of mesonotum black, with a intraalar microtrichiose stripe well separated from supraalar seta. Wing membrane brown along veins (Fig. 5C), posterior margin of alula bare of microtrichia. Tibiae 1-3 bright reddish, without dark rings ........... tabanoides sp. nov. (Fig. 1K)

- Mesonotal pilosity entirely light (white or yellow), with a supraalar microtrichiose stripe (as in Fig. 4C). Wing membrane either clear or completely infuscated, alula entirely microtrichiose. Tibia 1 and 2 each with a dark ring, tibia 3 almost completely blackish.

11. Tergites $2+3$ with widely separated microtrichiose fasciae, tergite 4 with fasciae narrowly separated (Fig. 7J). Vertex almost bare of microtrichia (the very few microtrichia do not form a distinct pattern) (Fig. 2K). Wing membrane light brown ........ ochreatus (Hull, 1964) comb. nov. (Fig. 1J)

- Tergites 2-4 with fasciae (Fig. 7G, H). Vertex extensively densely microtrichiose (Fig. 2H, I). Wing membrane clear ........................................................................... 12

12. Wing with yellow veins, microtrichia equally dense and light (yellowish) on whole wing, appearing unicolorous (Fig. 5A). Frons, except for a stripe along the lunula, and vertex except for a narrow stripe at posterior edge entirely densely covered by yellowish microtrichia (Fig. 2H). Setae on all parts of the body golden. Tergites without black setae

M. apiformis sp. nov. (Fig. 1G)

- Wing with brown veins, in proximal half densely covered by white microtrichia, in distal half with dark microtrichia, thereby wing appearing bicoloured (Fig. 5B). Nearly whole frons and a large posteromedian area on vertex without microtrichia (Fig. 2I). Tergites extensively black setose ...

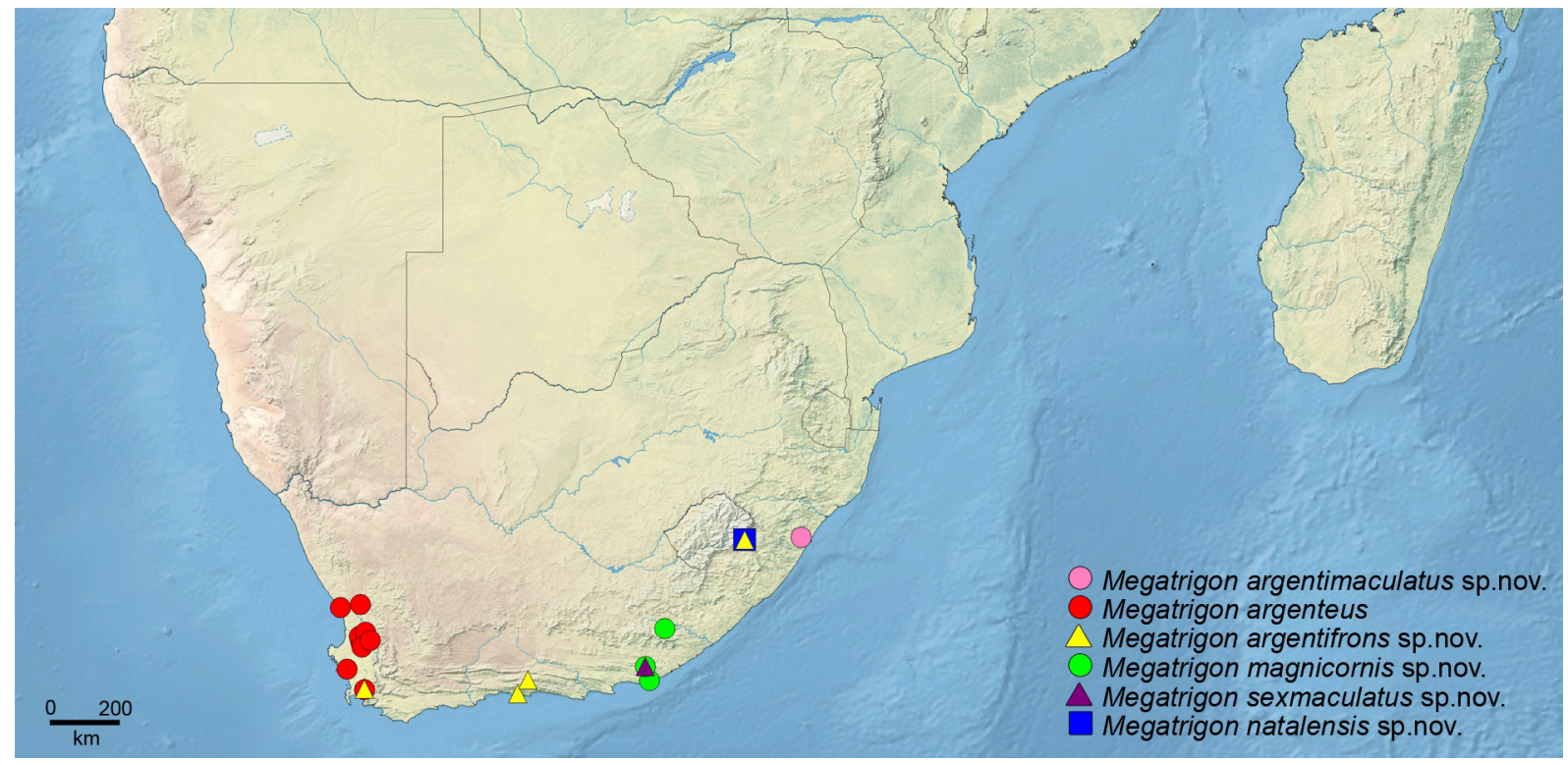

Fig. 15. Megatrigon argenteus species group (subgroup 1), distribution. 


\section{Discussion}

Eumerus (s. l.) is arguably the morphologically most diverse genus-group taxon of the family Syrphidae. As currently recognized, it contains about 300 described species (Pape \& Thompson 2010), and many more await discovery and description. There is growing evidence that Eumerus (s.l.) is paraphyletic (e.g., Doczkal \& Pape 2009), which means that Eumerus will have to either be widened to encompass the Merodon genus group with the morphologically rather distinct genera Merodon, Platynochaetus, Lyneborgimyia and Azpeytia, or to be split into a number of genera. Merodon is in itself a speciesrich genus, containing some 160 described species (Pape \& Thompson 2010), and dozens of species are awaiting description (A. Vujić, pers. comm.). Merodon is well defined and has been in use for considerable time, and transferring its species to Eumerus may seem as nomenclaturally destabilising by going against current usage, and a transfer would moreover create many secondary homonyms. From a practical point of view, splitting Eumerus (s.l.) into smaller, named units may seem inescapable as a means of efficient communication, and whether these are given informal or scientific names, and in case of the latter whether a rank of genus or subgenus is applied, is largely a matter of personal preferences. As mentioned above, the species here united in the genus-group taxon Megatrigon share several autapomorphies (e.g., lower calypter of wing with long pile dorsally, metafemur with striae, male genitalia with long microtrichia on subepandrial sclerite, well-defined and narrow posterior surstyle lobe, and S shaped hamus of hypandrium), which are so distinct that this arguably is one of the most strongly corroborated clades of the tribe Merodontini, and the rank of genus is here considered as fully justified.

Megatrigon is an endemic Afrotropical taxon with its centre of diversity in the dry southern parts of the continent (Figs 15-16). Most of the recognized species are present in the Cape Region, which is one of the most species-rich centres of bulbous plants. Of almost 1200 species of bulbous plants in this region, three-quarters are endemic (Manning et al. 2002). It seems quite probable that species of Megatrigon, like the sapro-phytophagous genera and phylogenetically close relatives Merodon and Eumerus, are associated with geophytes during the larval stage, and the predominantly southern African distribution could be explained by the marked diversity of the potential host plants in this region.

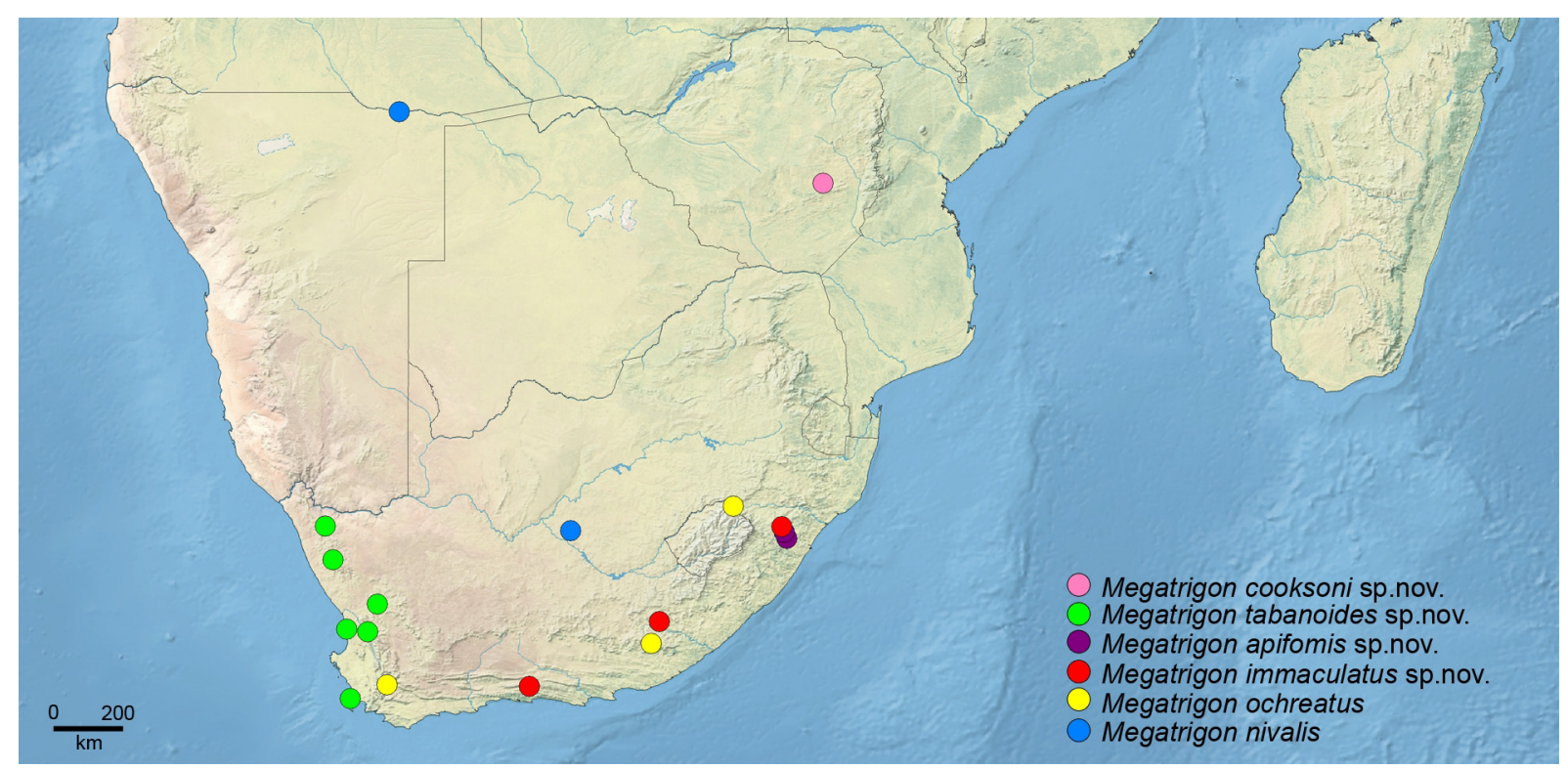

Fig. 16. Megatrigon nivalis and M. argenteus species group (subgroup 2), distribution. 
All species of Megatrigon currently known are rare in collections, and a considerable number is still known from one or two specimens only, thereby indicating that a considerable number of species are yet to be discovered.

\section{Acknowledgements}

We are sincerely grateful to the many curators that generously arranged for the numerous loans of both identified and unidentified material of Afrotropical Eumerus (sensu lato) necessary for completing the present revisionary work, and we are appreciative of the professional conduct and understanding we have met when returning loans that were long overdue. We sincerely apologise for the unexplained loss or misplacement of a few specimens caused by the untimely death of Leif Lyneborg in 2006. The research has been supported by a travel grant from the SYNTHESYS programme (http://www.synthesys. info/) financed by the European Community Research Infrastructure Action under the FP7 Integrating Activities Programme, allowing DD to sort out relevant material on loan to LL from various sources. SR acknowledges partial support from the Ministry of Education, Science and Technological Development of the Republic of Serbia (project No. 173002, 1613001).

\section{References}

Doczkal D. \& Pape T. 2009. Lyneborgimyia magnifica gen. et sp. n. (Diptera: Syrphidae) from Tanzania, with a phylogenetic analysis of the Eumerini using new morphological characters. Systematic Entomology 34: 559-573. http://dx.doi.org/10.1111/j.1365-3113.2009.00478.x

Hippa H. \& Ståhls G. 2005. Morphological characters of adult Syrphidae: descriptions and phylogenetic utility. Acta Zoologica Fennica 215: 1-72.

Hull F.M. 1964. Diptera (Brachycera): Syrphidae. South African Animal Life 10: 443-496.

Johnson C.W. 1898. Diptera collected by Dr. A. Donaldson Smith in Somaliland, eastern Africa. Proceedings of the Academy of Natural Sciences Philadelphia 50: 157-164. Available from http:// biodiversitylibrary.org/page/26368835 [accessed 6 Sep. 2016]

Macquart P.-J.-M. 1855. Diptères exotiques nouveaux ou peu connus. 5.e supplément. N.E. Roret, Paris. Available from http://biodiversitylibrary.org/page/35274626 [accessed 14 Oct. 2016]

Manning J.C., Goldblatt P. \& Snijman D. 2002. The Color Encyclopedia of Cape Bulbs. Timber press, Cambridge, UK.

McAlpine J.F. 1981. Morphology and Terminology - Adults. In: McAlpine J.F., Peterson B.V., Shewell G.E., Teskey H.J., Vockeroth J.R. \& Wood D.M. (eds) Manual of Nearctic Diptera. Vol. 1: 9-63. Monograph No. 27, Research Branch, Agriculture Canada, Ottawa.

Pape T. \& Thompson F.C. (eds) 2010. Systema Dipterorum, version 1.5. Available from http://www. diptera.org [accessed 21 June 2015].

Ricarte A., Marcos-García M.Á. \& Rotheray G.E. 2008. The early stages and life histories of three Eumerus and two Merodon species (Diptera: Syrphidae) from the Mediterranean region. Entomologica Fennica 19: 129-141.

Rotheray G.E. \& Gilbert F.S. 2011. The natural history of hoverflies. Forrest Text, Tresaith, Wales, UK.

Shannon R.C. (1927) A new genus and five new species of Syrphidae from Australia (Diptera). Proceedings of the Entomological Society of Washington 29: 82-87. Available from http://www. biodiversitylibrary.org/page/16195913 [accessed 17 Oct. 2016] 
Sinclair B.J. 2000. Morphology and terminology of Diptera male terminalia. In: Papp L. \& Darvas B. (eds) Contributions to a manual of Palaearctic Diptera (with special reference to flies of economic importance), Vol. 1: 53-74. Science Herald Press, Budapest.

Smith K.G.V. \& Vockeroth J.R. 1980. Family Syrphidae. In: Crosskey R.W. (ed.) Catalogue of the Diptera of the Afrotropical Region: 488-510. British Museum (Natural History), London.

Speight M.C.D. 1987. External morphology of adult Syrphidae (Diptera). Tijdschrift voor Entomologie 130: $141-175$.

Speight M.C.D. 2014. Species accounts of European Syrphidae (Diptera), 2014. Syrph the Net, the database of European Syrphidae, vol. 78, Syrph the Net publications, Dublin.

Ssymank A., Kearns C.A., Pape T. \& Thomson F.C. 2008. Pollinating flies (Diptera): A major contribution to plant diversity and agricultural production. Tropical Conservancy 9: 86-89. http://dx.doi.org/10.108 $\underline{0 / 14888386.2008 .9712892}$

Stuckenberg B.R. 1999. Antennal evolution in the Brachycera (Diptera), with a reassessment of the terminology relating to the flagellum. Studia dipterologica 6: 33-48.

Walker F. 1852. Diptera. Part III. In: Insecta Saundersiana: or Characters of Undescribed Insects in the Collection of William Wilson Saunders, Esq., F.R.S., F.L.S., \&c. Vol. 1: 157-252. Van Voorst, London. http://dx.doi.org/10.5962/bhl.title.5112

Manuscript received: 10 August 2015

Manuscript accepted: 27 April 2016

Published on: 20 October 2016

Topic editor: Koen Martens

Desk editor: Kristiaan Hoedemakers

Printed versions of all papers are also deposited in the libraries of the institutes that are members of the EJT consortium: Muséum national d'Histoire naturelle, Paris, France; Botanic Garden Meise, Belgium; Royal Museum for Central Africa, Tervuren, Belgium; Natural History Museum, London, United Kingdom; Royal Belgian Institute of Natural Sciences, Brussels, Belgium; Natural History Museum of Denmark, Copenhagen, Denmark; Naturalis Biodiversity Center, Leiden, the Netherlands. 